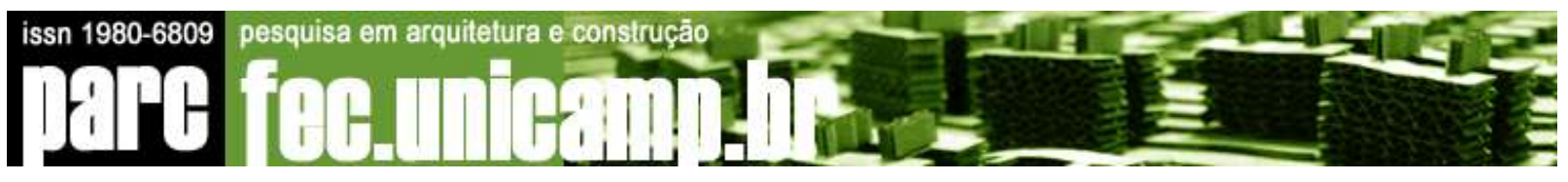

\title{
Análise de três vilas de São Paulo por meio de conceitos convergentes
}

Analysis of three São Paulo villages through convergent concepts

\author{
GEISE BRIZOTTI PASQUOTTO
}

ANA CARLA FONSECA REIS

MARIA DE FÀTIMA LOURENÇO NUNES

Graduada em Arquitetura e Urbanismo pela Faculdade de Arquitetura, Artes e Comunicação da Universidade Estadual Paulista "Julio de Mesquita Filho" - UNESP e mestre em Engenharia Civil na área de Arquitetura e Construção pelo Programa de Pós-Graduação da Universidade Estadual de Campinas - UNICAMP.

Graduada em Administração Pública pela Fundação Getúlio Vargas-FGV e em Administração de Empresas pela Universidade de São Paulo-USP, MBA pela Fundação Dom Cabral, mestre em Administração de Empresas e Doutora em Planejamento Urbano e Regional pela Universidade de São Paulo - USP.

Graduada em Educação Artística e pós-graduada em Artes Plásticas pela Faculdade Santa MarcelinaFASM e mestre em Educação, Arte e História da Cultura pela Universidade Presbiteriana Mackenzie.

geisebp@gmail.com

anacarla@garimpodesolucoes.com.br

fatimalou@hotmail.com

\section{Resumo}

O presente trabalho tem por objetivo apresentar três conceitos complementares e contemporâneos: cidades criativas, marketing urbano e visual merchandising. De modo a ilustrar essas vertentes conceituais na prática, será analisado o grau de sua aplicação conjunta a três bairros da cidade de São Paulo, com características e momentos de desenvolvimento distintos: Vila Madalena, Vila Mariana e Vila Leopoldina. 


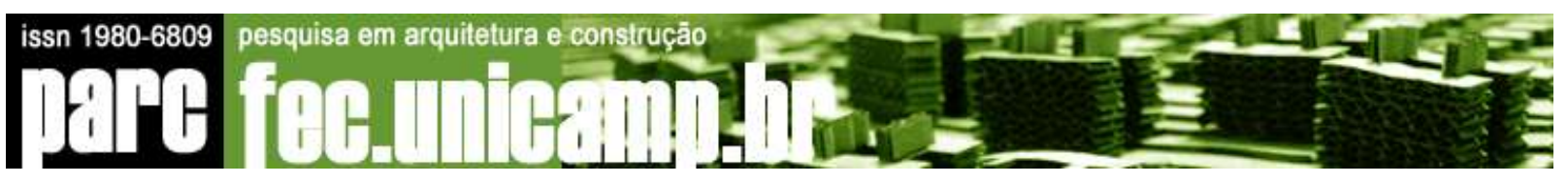

Palavras-chave: Cidades Criativas, Marketing Urbano, Visual merchandising, São Paulo.

\section{Abstract}

The current paper aims to present three complementary and contemporary concepts: creative cities, city marketing and visual merchandising. In order to bring them live, the authors will analyse the level of their joint application to three neighbourhoods of São Paulo: Vila Madalena, Vila Mariana and Vila Leopoldina

Keywords: Creative Cities, City Marketing, Visual merchandising, São Paulo. 


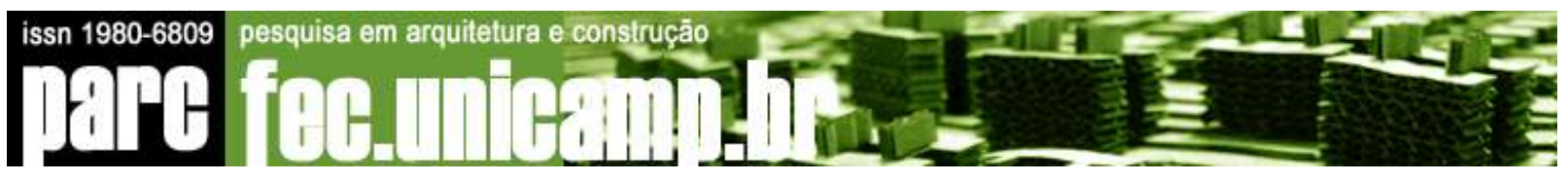

\section{Análise de três vilas de São Paulo por meio de conceitos convergentes}

\section{Introdução}

A paisagem de uma cidade, seus fluxos e as relações entre pessoas apenas podem ser entendidas em sua plenitude quando abordadas de maneira plural e sistêmica, tratando a cidade em sua transversalidade setorial. A presente análise se propõe a apresentar três abordagens a essa visão caleidoscópica: cidades criativas, marketing urbano e visual merchandising. A apresentação da cidade mundial, seu modo de se fazer ver, sentir e gerar aspirações por meio da comunicação de uma imagem específica caracteriza o marketing urbano. Por outro lado, a atração de talentos, a vivacidade criativa e a inserção dela são características vitais das cidades criativas. A partir dessas constatações, o visual merchandising expande a relação entre externo e interno, da faixa de transição entre a loja e a rua, como a apresentação da cidade ao mundo.

A estrutura deste trabalho terá início, portanto, com uma breve explanação de cada um dos três conceitos mencionados. Para ilustrá-los na prática, elegemos três vilas de São Paulo, com histórico, momento de transição e busca de identidade peculiares: Vila Madalena, Vila Mariana e Vila Leopoldina. Antigos bairros paulistas, cujo passado ainda hoje se faz presente, mas com cores e nuances que se esvanecem na busca de um espaço na São Paulo contemporânea.

\subsection{Cidades Criativas}

O conceito de cidades criativas surge na segunda metade da década de 1990, impulsionado pelas discussões acerca de uma nova economia: a economia criativa. Esta, por um lado, caracteriza-se pela centralidade do conhecimento na geração de competitividade regional; na atuação global de setores econômicos, mercados e finanças, possibilitada pelas novas tecnologias; na organização em redes (CASTELLS, 2000).

Por outro lado, a economia criativa acrescenta a esses fatores novas respostas a um contexto geopolítico que, ao se deparar com a queda do potencial diferenciador das manufaturas, incorporou às novas tecnologias um contraponto fundamental de caráter cultural. 
Conceito de contornos fluidos, ainda em formação, a economia criativa surgiu na Austrália, em 1994 e tem como seu maior expoente o Reino Unido, onde foi adotada pelos Trabalhistas de Blair, em 1997, como base da estratégia nacional de recuperação econômica. Para estes, as indústrias criativas têm por essência a criatividade individual, habilidades e talento, capazes de gerar riqueza e empregos por meio de direitos de propriedade intelectual. O forte caráter tecnológico associado a patentes, design industrial é assim balanceado pelo reconhecimento da importância dos direitos autorais e até das marcas registradas e indicações geográficas típicas, que trazem em seu bojo o reconhecimento da diferenciação do que é produzido em um espaço. A delimitação de treze indústrias criativas no país formalizou o que entende-se por berço e palco da criatividade: propaganda, arquitetura, música, artes visuais e do espetáculo, edição, rádio e TV, antiguidades, design, moda, software/jogos de computador/publicações eletrônicas e artesanato (DCMS, 1997). Treze setores nos quais, claramente, o Reino Unido se considera detentor de vantagem competitiva global.

A partir dos primeiros anos desta década, abordagens alternativas começaram a surgir, tentando adaptar o conceito ao contexto local. Na própria Europa, o estudo da Comissão Européia (2006) tenta deslindar o que, em uma visão regional, poder-se-ia entender por cultura e criatividade, dois conceitos com fortes contrastes de interpretação por cada um dos 27 países do bloco. Assumindo a importância de ambos como inputs de produção, foram traçados círculos concêntricos, tendo por núcleo as artes e se expandindo para as indústrias culturais (primeiro anel) e as indústrias criativas (último anel). Ao passo que as indústrias culturais ancoram-se nas artes, tendo caráter essencialmente cultural (música, audiovisual, fotografia, livros etc.), as indústrias criativas produzem bens e serviços funcionais, que se nutrem de elementos culturais (moda, design, arquitetura, software, games etc.).

As cidades criativas nascem, assim, como locus dessa nova economia, cuja representatividade chegaria a 7\%-8\% do PIB mundial (UNCTAD). Enquanto a maioria dos autores que se dedicam ao tema não apresenta uma definição clara de cidade criativa, destaca-se a definição cunhada pela Canadian Policy Research Networks (2004):

Cidades criativas são locais de experimentação e inovação, onde novas idéias florescem e pessoas de todas as áreas se unem para fazer de suas comunidades lugares melhores para viver, trabalhar e se divertir. Baseiam-se em tipos diferentes de conhecimento, pensam holisticamente e agem sabendo da interdependência econômica, social, ambiental e cultural; usam a 


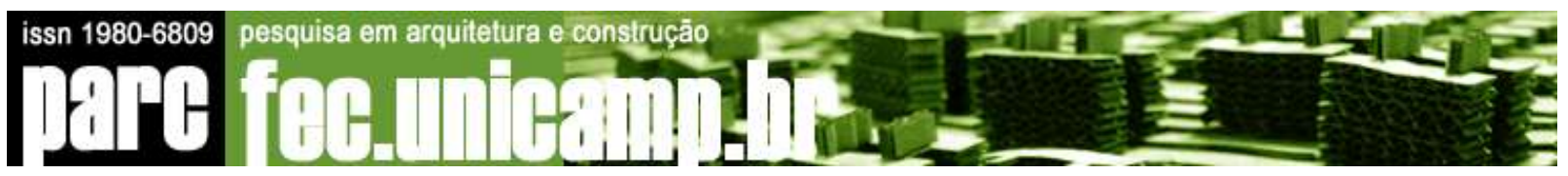

participação pública para lidar com temas complexos, (...) e problemas urbanos perenes de habitação, inclusão, preservação e desenvolvimento.

\subsection{Marketing Urbano}

Os anos de 1990 são caracterizados pelo denominado Planejamento Estratégico, que segundo Lopes (1998), “(...) tornou-se um instrumento indispensável para pensar o futuro das cidades e direcionar o seu desenvolvimento, dentro do novo espaço de fluxos de um mundo globalizado e de uma sociedade em rápida evolução". Algumas cidades se destacam por esse planejamento, e tornaram-se elementos de discussão e de base para outras intervenções. Na Europa, o caso de Barcelona é paradigmático. Posteriormente, houve experiências em Paris, Brimingham, Frankfurt, Lyon, Madrid, Bilbao, Valença, Malaga e Lisboa. Nos Estados Unidos e Canadá podemos destacar São Francisco, Montreal e Toronto. Na América Central, México, observa-se Monterrey e Guadalajara e na América do Sul destaca-se a Argentina (Rosário, Mendonza e Buenos Aires), a Colômbia (Bogotá, Medellin, Calle e Cartagena) e o Brasil (Rio de Janeiro e outras em fase de planejamento, como Fortaleza, Campos, Juiz de Fora, Belo Horizonte e Recife).

Verifica-se que através da "economia global da sociedade em rede" (LOPES, 1998), um dos principais objetivos das cidades globais é a competitividade utilizada para "responder às demandas globais e atrair recursos humanos e financeiros internacionais" (BORJA \& FORN, 1996). Diante disso, as cidades, com a necessidade de assegurarem um status determinado, exercem consequências marcantes para o planejamento. Desta forma, a venda das cidades passa a fazer parte do novo planejamento urbano (BENACH, 1997). Para tanto, é de grande valia a repercussão que uma intervenção ocasiona, tanto no âmbito local como global. Nesse contexto, torna-se essencial uma ferramenta do planejamento urbano chamado marketing urbano.

O Marketing Urbano é uma ramificação do planejamento estratégico que visa a associação de ações para a promoção das cidades, tornando-a atrativa e competitiva. Ele esta cada vez mais sendo utilizado no desenvolvimento e planejamento das cidades de grande porte ou turísticas, adquirindo, segundo Sanchez (1997) uma centralidade no conjunto das novas políticas urbanas, tornando-se o principal instrumento para alavancar diversos processos de promoção urbana.

O processo de marketing urbano e sua influência no planejamento, como identifica Sanchez (1999), ocorre pela facilidade com que essa ferramenta incorpora novas tecnologias de 
comunicação e informação, e que, através do vínculo com novas políticas e representações sociais, interfere na renovação das formas espaciais e imprime marcas no espaço urbano.

As principais ferramentas do marketing urbano são: i) a arquitetura icônica, ii) os eventos emblemáticos, iii) as "marcas", iv) o discurso/slogan/logotipo e v) as parcerias públicoprivadas (PASQUOTTO, 2011). Essas ferramentas são interdependentes, isto é, para o marketing urbano ocorrer de fato, deve-se usar associações dessas ferramentas, pois um tópico relaciona-se com o outro.

O planejamento estratégico, utilizando o marketing urbano, possui muitas qualidades, como a atração de investimentos e pessoas, o incremento do turismo, a competitividade mundial, entre outros. Entretanto, ele também acarreta alguns malefícios que precisam ser revistos, como: i) o descolamento da população com os cenários "criados", ii) o enfraquecimento da cultura local, iii) a padronização arquitetônica e urbanista pela utilização das "marcas" e iv) as parcerias ditando "como" e "aonde" intervir (PASQUOTTO, 2011).

\subsection{Visual merchandising}

Pertencente a um mundo repleto de necessidades e desejos, a vitrina transparece pelos mais diferentes espaços a intenção de vender. Entende-se por vitrina, portanto, todo espaço com exposição de produtos, cuja finalidade e objetivo principal é a comercialização.

Sendo um espaço muito caro para ser unicamente a imagem ou a representação da filosofia de um determinado tipo de comércio, deve tornarse uma atração, um espetáculo visual, com a função precisa de estimular o consciente e o inconsciente do consumidor a dirigir seus passos para o local de venda e aí realizar a compra (DEMETRESCO, 1990, p.18).

Pode-se considerar que a vitrina é toda a exposição de mercadorias encontrada em uma loja. Isso significa que, além da vitrina convencional (tradicional), que expõe produtos próximos à fachada da loja, toda a distribuição de mercadorias expostas à venda no interior do estabelecimento, também é vitrina.

O objetivo da vitrina é expor produtos para a venda. Para que isso aconteça, uma exposição bem montada se faz necessário, tornando o produto mais atraente, causando impacto visual, enviando um apelo psicológico e estabelecendo um diálogo com o consumidor.

A vitrina pode exibir lançamentos e novidades de mercado, em relação a todo o tipo de produto, mostrando novo design e tecnologia, responsabilizando-se por retratar diversos aspectos da atualidade, que são definidos como "funções" (social, informativa e emotiva). 


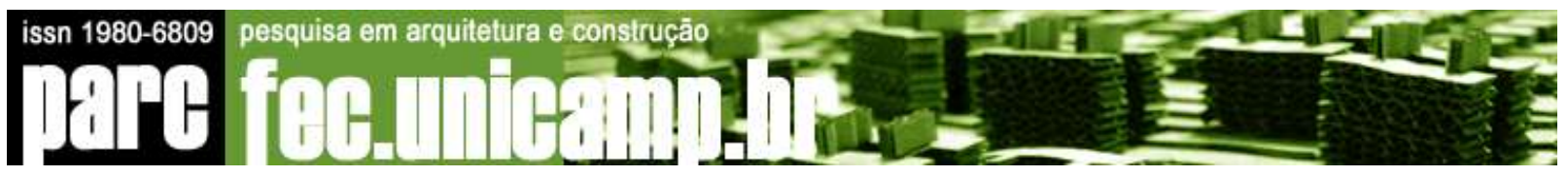

O vitrinista é o elemento de contato entre os interesses do comércio e os do consumidor. Num processo de comunicação ele, através da vitrina, codifica e emite uma mensagem de acordo com a política de venda da empresa. Seu trabalho começa na idealização, passa pela execução, (utilizando técnicas artesanais e industriais) e termina na montagem. Tem como objetivo final a correta apresentação de produtos ou serviços na vitrina, que é o elo entre a loja e o cliente.

A vitrina predispõe o público, estimulando o desejo de compra que é o caminho natural da venda. Pode ser considerada como um vendedor eloquente, permanente e ativo, seja pela força de sua exposição ou pela originalidade de sua concepção.

Em uma época onde o planejamento estratégico (dito empresarial) está presente na evolução urbana, a exposição da cidade e seu impacto mundial, processos observados na elaboração de uma vitrina, tornam-se ferramentas importantes de atração e venda da cidade. Assim a relação do visual merchandising com o marketing urbano se aproximam.

\section{As Vilas de São Paulo}

A escolha da Vila Madalena, da Vila Mariana e da Vila Leopoldina como base de estudo prático se deveu por uma confluência de dois motivos:

a) transformação recente de sua estrutura urbana, comercial e cultural, em oposição a um passado recente de bairros com características residenciais (Vila Mariana e Vila Madalena) e fabris (Vila Leopoldina) marcantes, conforme será brevemente detalhado.

b) diferentes graus de maturidade de posicionamento dos três bairros, que atravessam momentos distintos em sua relação com a cidade contemporânea. Assim, a Vila Madalena encontra-se consolidada como pólo de vivacidade noturna e com prevalência de comércio voltado ao artesanato, à moda alternativa e a negócios contemporâneos e de tendências. $A$ Vila Mariana, por sua vez, tem vivido transformação recente, impulsionada pela consolidação em um quadrilátero exíguo de centros acadêmicos voltados a artes e comunicações (dois campi da ESPM, Faculdade de Belas Artes), com a consequente proliferação de negócios, serviços e atividades noturnas dedicadas a esses setores e público, complementado por equipamentos culturais de impacto (Cinemateca Brasileira, SESC Vila Mariana). Já a Vila Leopoldina, que viu seus galpões e fábricas de meados do século passado entrarem em decadência, dá indícios de despontar agora como pólo criativo de audiovisual e comunicações. 


\subsection{Vila Madalena}

A Vila Madalena nasceu como "Vila dos Farrapos" no ano de 1910. Era uma parte de Pinheiros, uma extensa região que se espraiava, no início da ocupação de São Paulo, desde a várzea do Rio Pinheiros até o espigão da Paulista. No início do século XIX, a área - então chamada de Sítio do Buraco - pertencia a um grande fazendeiro português, proprietário de muitas terras. Ele tinha três filhas: Ida, Beatriz e Madalena, que deram origem aos nomes dos atuais bairros da Vila Beatriz, Vila Ida e Vila Madalena. Entretanto, a história faz parte da memória oral dos habitantes da Vila.

A eletricidade apareceu apenas em 1928, onde a Vila era apenas um pequeno aglomerado de casas. Somente na década de 50 as ruas de terra começaram a ceder lugar ao asfalto.

$\mathrm{Na}$ década de 1960, o bairro passou a abrigar a população de estudantes, funcionários e professores da então recém-inaugurada Cidade Universitária da USP.

"No início da década de 70, o governo militar fechou o Conjunto Residencial da Universidade de São Paulo (Crusp) - alojamento universitário da USP." (PONCIANO, 2004, p. 310). A região foi invadida por um grupo de alegres estudantes, que ao longo dos anos foi revigorando o aspecto da Vila. A partir dos anos 80, começaram a surgir bares e uma série de negócios incrementados (galerias de arte, ateliês e lojas de grife).

Hoje, a Vila Madalena reúne moradores tradicionais, que ainda possuem casas simples com grandes terrenos (com criação de patos, galinhas etc.) e vários artistas e intelectuais. Integra o distrito de Pinheiros, tendo por vizinhos os bairros de Vila Nogueira, Jardim das Bandeiras, Jardim Paulistano, Jardim Europa e Pinheiros.

Uma das características marcantes da Vila é o nome de suas ruas, que segundo historiadores, foram batizadas por sugestão de estudantes de movimento anarquista, que deram nomes poéticos, eliminando a tradição urbana de homenagear autoridades públicas. Outros relatam que as ruas têm nomes recebidos pelos próprios moradores (que não possuíam na época escolaridade) e, portanto, colocavam nomes de substantivos simples como Girassol e Harmonia.

O burburinho da Vila Madalena, ou seja, o quadrilátero formado pelas Ruas Mourato Coelho, Aspicuelta, Harmonia e Rodésia é o mais alegre, colorido e movimentado do bairro. A arquitetura encontrada é formada por pequenas casas (geminadas ou não) pertencentes a um tempo primitivo da formação do bairro (FIGURA 01). Muitas são comerciais e outras, em número menor, ainda são habitadas por moradores tradicionais. Normalmente as residenciais 


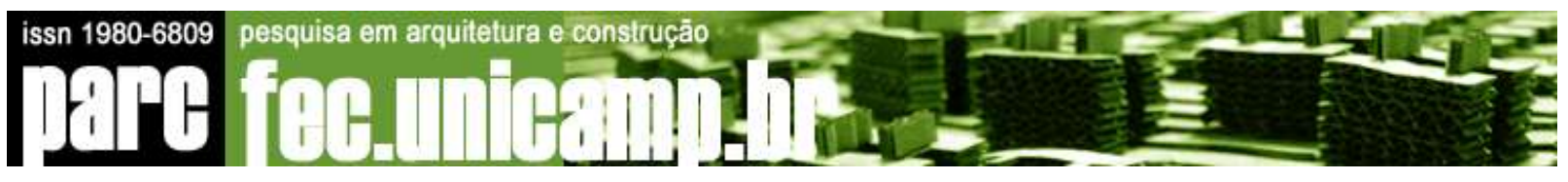

permanecem com as fachadas antigas, enquanto que as comerciais foram reformadas ou restauradas, e desta forma transformaram-se em graciosas casinhas com layouts alegres, artísticos, divertidos, rústicos ou contemporâneos, de acordo com o comércio que nelas se instalou (FIGURA 02).

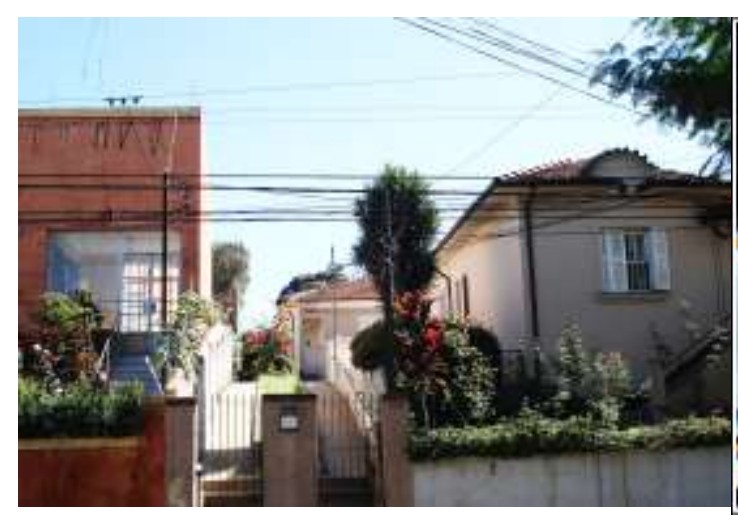

FIGURA 01 - Fachada das Casas na Vila. FONTE: Geise B. Pasquotto, 2007.

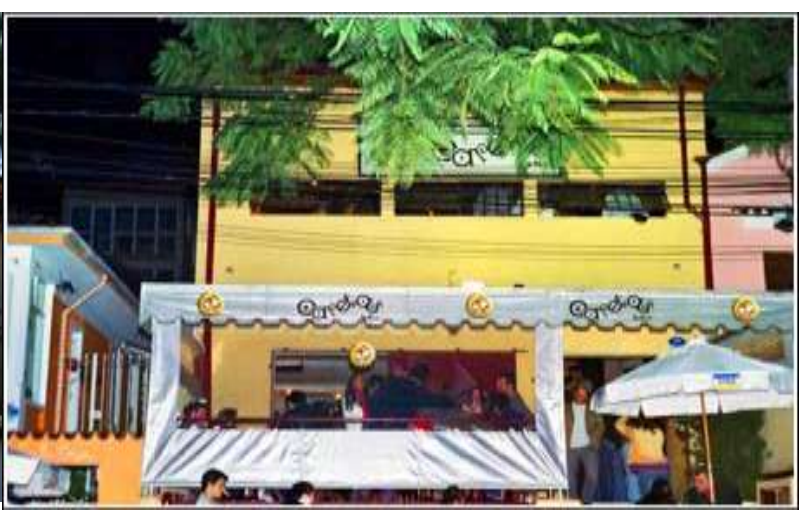

FIGURA 02 - Fachada de bar da Vila Madalena. FONTE: www.museodapessoa.net

Existem também pequenos edifícios construídos na segunda metade do século passado, que por conta da pouca altura, não interferem na paisagem urbana central.

É também característica da Vila, as escadarias ladeadas por muros (que são o elo entre as ruas paralelas) e os becos (corredores grafitados).

O beco do Batman é exemplo de espaço público que foi transformado com a ajuda dos grafiteiros e até mesmo de pichadores. O trabalho teve início em 1999 e hoje já espalhou frutos pela cidade, com a parceria entre uma organização não-governamental (ONG) e pichadores (FIGURA 03). 

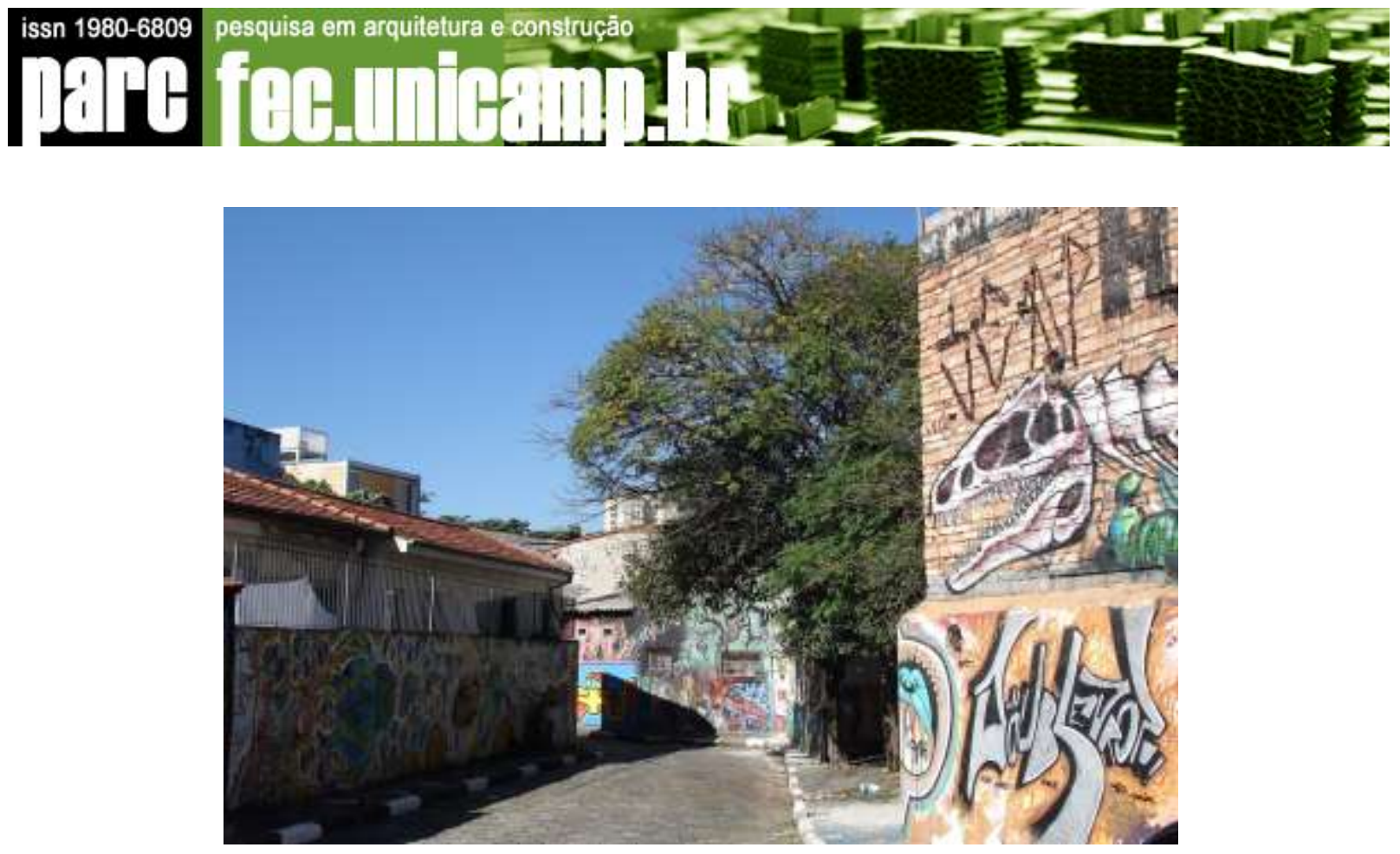

FIGURA 03 - Foto de muros grafitados do beco FONTE: Geise B. Pasquotto, 2007.

Atualmente o bairro agrega um público que reúne moradores tradicionais com artistas e intelectuais. Possui Ruas que preservam casas que foram construídas no início do século passado, juntamente com edificações luxuosas que elevam a Vila Madalena à bairro nobre, com poder sócio-econômico elevado. Os edifícios, alguns lofts, mostram que a Vila continua evoluindo.

As Ruas Harmonia, Girassol e Fidalga (o coração da Vila) são formatadas por casas até a Rua Wisard, quando a paisagem perde sua alegria e seu céu para outra grande "muralha" de arranha - céus. Outra "muralha" são os blocos de prédios habitacionais, todos de quatro andares, que ladeiam a praça pertencente à Rua José Carlo Burle. Mudam a paisagem desse lado da Vila, devido à massificação.

Um documentário, finalizado em 2004, retrata o início do bairro da Vila Madalena e seu desenvolvimento urbano, revelando que a cidade de São Paulo cresceu de forma desordenada, unindo pessoas de diferentes níveis sociais e econômicos em um espaço cada vez menor. A favela que existia, foi removida no final do primeiro semestre de 2005, que será o tema do próximo filme de Nehring. A documentarista filmou todo o processo de despejo, a derrubada dos barracos e o debate entre os ex-moradores sobre a situação, analisando os reais motivos que os levaram a serem expulsos do local.

No setor comercial as lojas de griffe, design e artesanato são o ponto alto da região, apresentando produtos diferenciados onde a originalidade e criatividade são fatores 


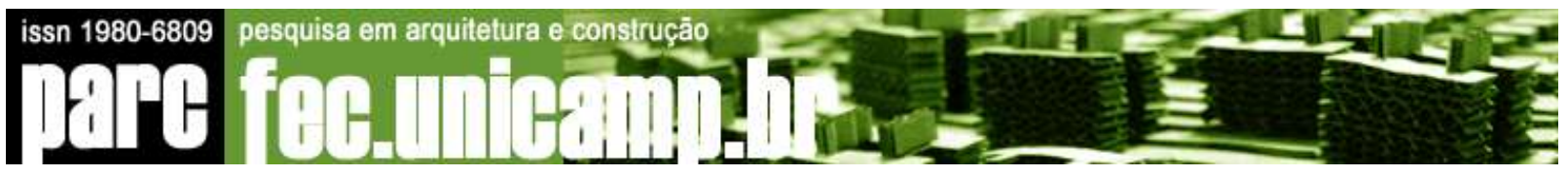

competitivos e de decisão de compra, criando atração e sedução para os visitantes (FIGURA 04 e 05).

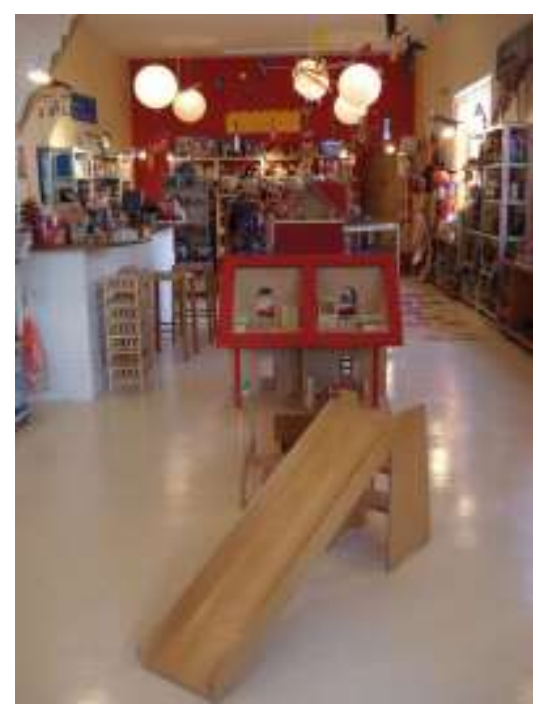

FIGURA 04 - Loja de binquedos artesanais de madeira.

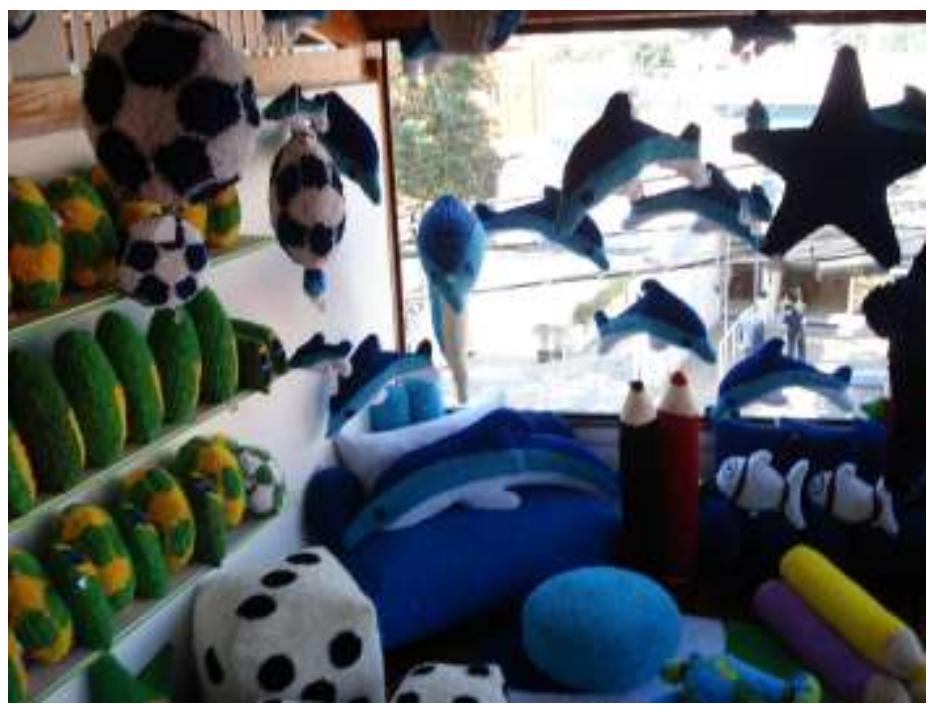

FIGURA 05 - Loja especializada em objetos em "fuxico". FONTE: Geise B. Pasquotto, 2007.

FONTE: Geise B. Pasquotto, 2007.

Os bares, cafés, casas noturnas e restaurantes, fazem com que ela seja conhecida por ser o reduto boêmio da cidade de São Paulo. As fachadas tendem a ser muito coloridas, (com inserção principalmente de mosaicos), criando uma atmosfera alegre e descontraída (FIGURA 06). Os mosaicos surgem também em muros e pisos, transformando os espaços públicos em ambientes diferenciados (FIGURA 07).

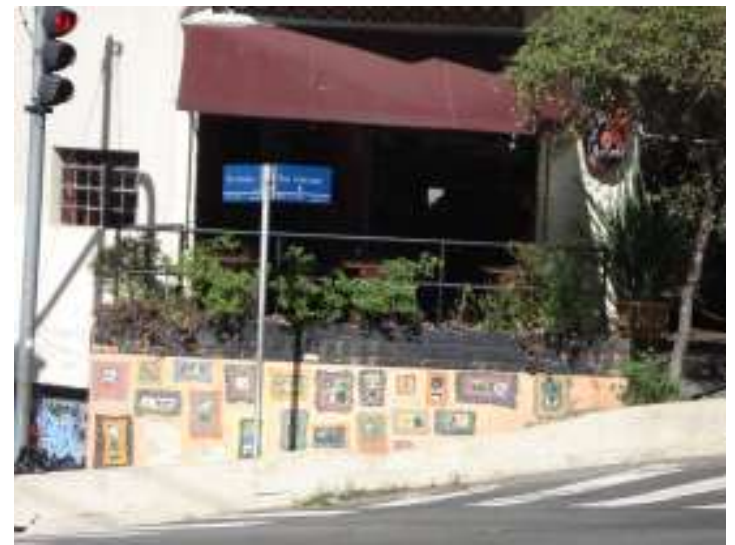

FIGURA 06 - Muro comercial com mosaico FONTE: Geise B. Pasquotto, 2007.

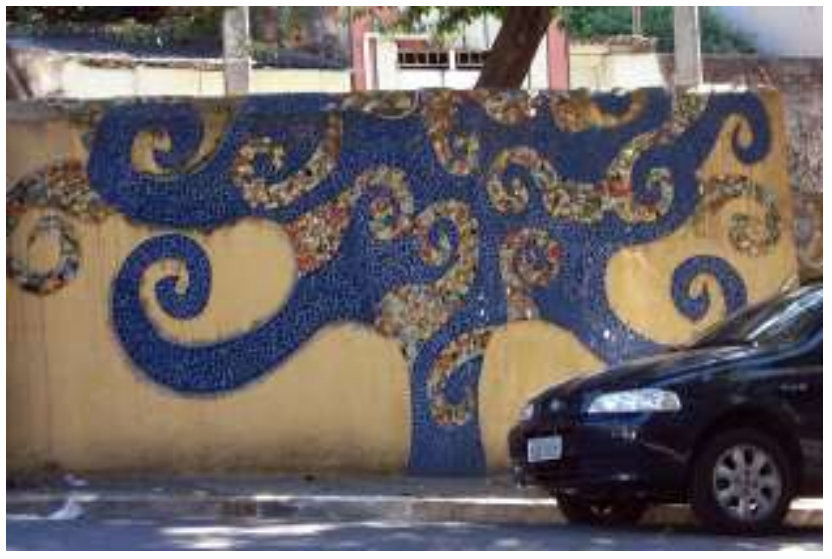

FIGURA 07 - Muros públicos com mosaicos. FONTE: Geise B. Pasquotto, 2007. 


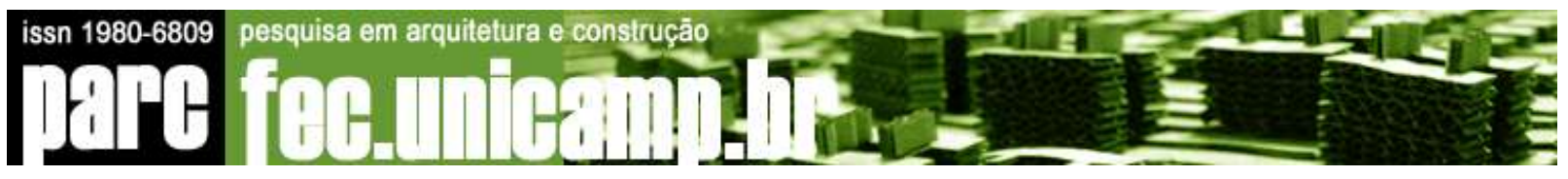

A criatividade chega até à pintura dos tapumes de uma construtora da região (FIGURA 08), entrando no clima de arte de toda a Vila.

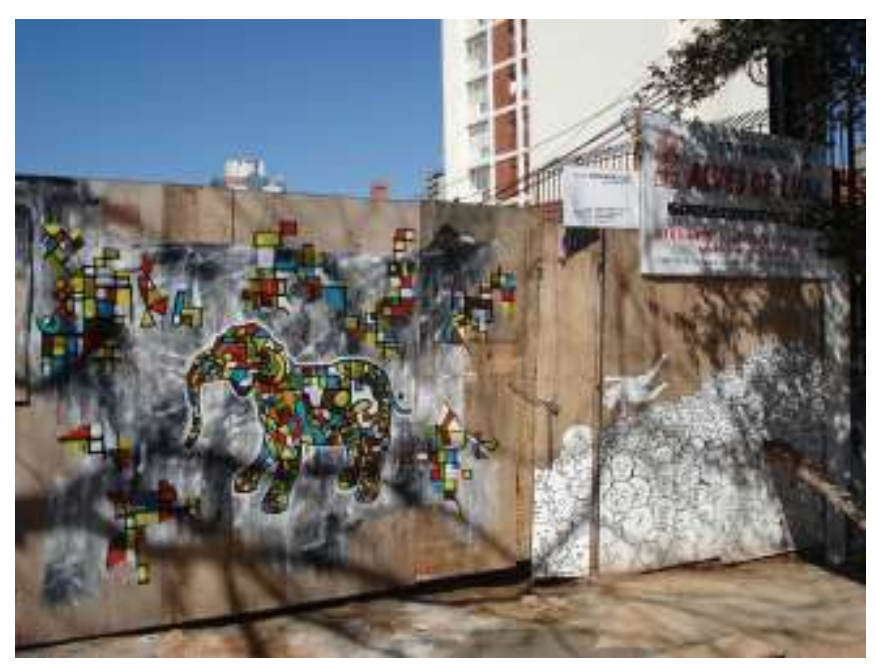

FIGURA 08 - Foto de pintura em tapume.

FONTE: Geise B. Pasquotto, 2007.

No setor cultural, as galerias de arte, as feiras, os festivais, os shows, as livrarias (FIGURA 09), escolas e ateliês de arte, estão em crescente progresso. Exemplo disso é um movimento que já acontece pelo terceiro ano consecutivo a "Arte da Vila" que vem sendo cada vez mais esperado pelos visitantes. Embora o bairro tenha tradição boêmia e artística forte, 0 movimento começa cedo, com pessoas buscando o que mais lhes interessa nos domínios da arte, tendo a oportunidade de adentrar em ateliês que comumente são fechados ao público. $\mathrm{Na}$ estação Vila Madalena do Metrô, os passageiros que querem percorrer esse trajeto encontram vans sinalizadas com a bandeira do evento. A "Arte da Vila" já faz parte do calendário turístico da cidade de São Paulo, recebendo inclusive visitantes de outros Estados. É a Vila juntamente com seu grupo de artistas plásticos e a prefeitura de São Paulo, trabalhando pela divulgação das atividades artísticas do bairro, onde ganham: setor privado e o terceiro setor, pois o evento tem a contribuição do Espaço Cidade Escola Aprendiz. 

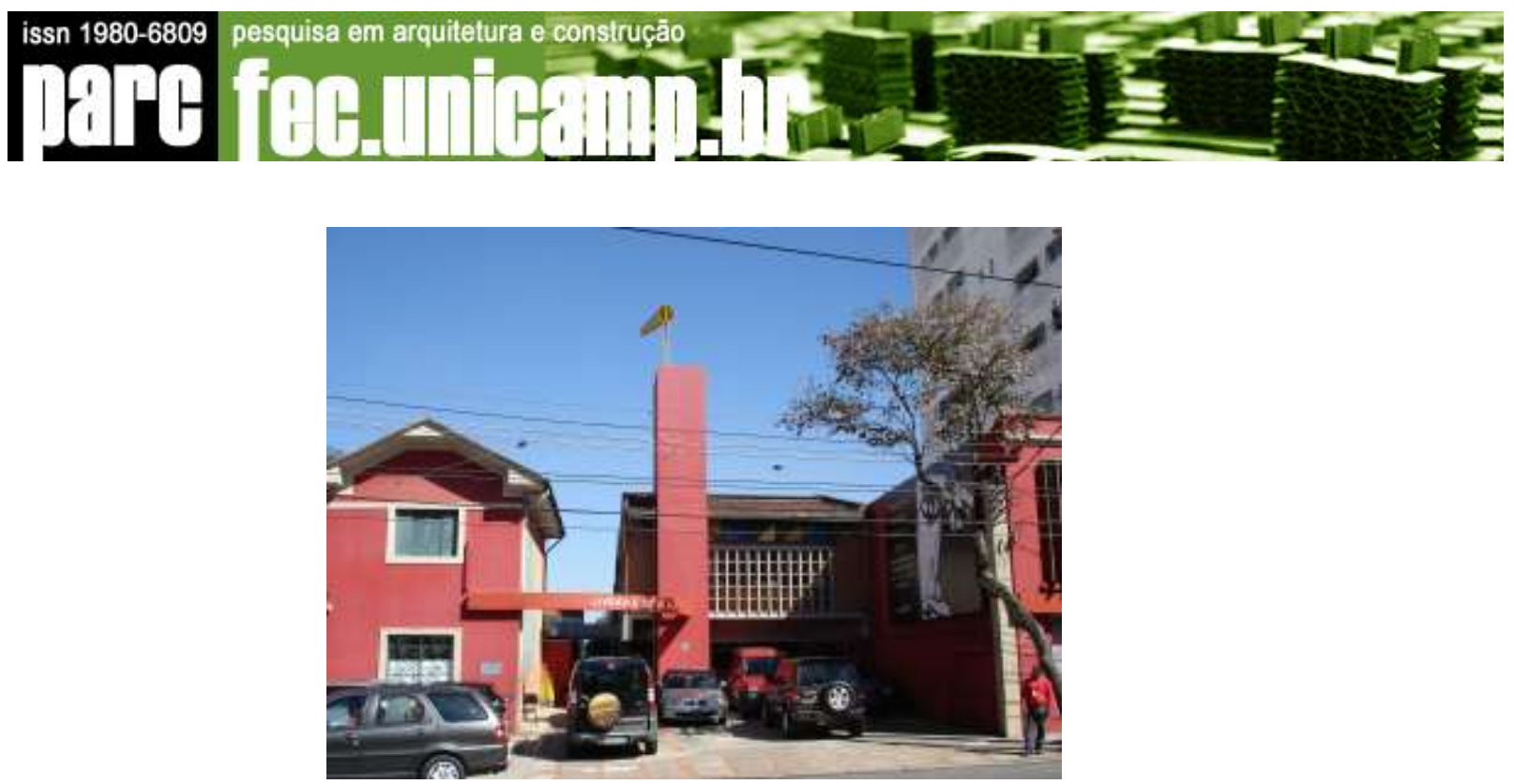

FIGURA 09 - Livraria da Vila.

FONTE: Geise B. Pasquotto, 2007

A Cidade Escola Aprendiz foi fundada em 1997 pelo jornalista Gilberto Dimenstein e objetiva integrar escola e comunidade, compondo uma vivência única de aprendizado onde praças, ateliês, livrarias, oficinas, estúdios, becos e cafés transformam-se em salas de aulas informais sintonizadas com os currículos escolares. O projeto surgiu como um site para alunos de escolas públicas e privadas, que se propunha à disseminação de temas relacionados à educação para a cidadania o www.aprendiz.org.br que existe até hoje, e é considerado uma referência de educação na Internet. A Cidade Escola Aprendiz ainda se destaca com outros programas, como: Oficinas de Mosaico, Café Aprendiz, Praça Aprendiz das Letras, Culinária Infantil. As aulas tem como objetivo, estimular na criança sua autoestima, desenvolver suas habilidades e conhecimentos.

Outras opções culturais são o "Teatro Escola Brincante" e o "Vila Viva". O TEB é um centro de pesquisa, estudo e difusão da cultura popular brasileira, comandado pelo artista pernambucano Antonio Nóbrega e sua mulher, a atriz e dançarina Rosane Almeida. $O$ Espaço tornou-se ponto de cultura e principal ação do Programa Cultura Viva, em 2004. Tem como objetivo preservar e divulgar a cultura popular brasileira. O "Vila Viva", que teve início no ano passado com o apoio da Prefeitura e do Departamento de Botânica da Universidade de São Paulo, passou a reconhecer as espécies de árvores existentes na região, colocando uma placa de identificação. A idéia está sendo semeada em bairros próximos e até em outras cidades. 
Em relação à vulnerabilidade social da Vila, foi possível por meio das informações do Índice Paulista de Vulnerabilidade Social (IPVS) da Fundação Sistema Estadual da Análise de Dados (SEADE), uma visão detalhada da condição de vida do município.

Abaixo segue o Mapa da Subprefeitura de Pinheiros (FIGURA 10), ao qual pertence a Vila Madalena. Segundo o mapa, a Vila (situada na região central do mapa) possui nenhuma (1) e muito baixa (2) vulnerabilidade social.

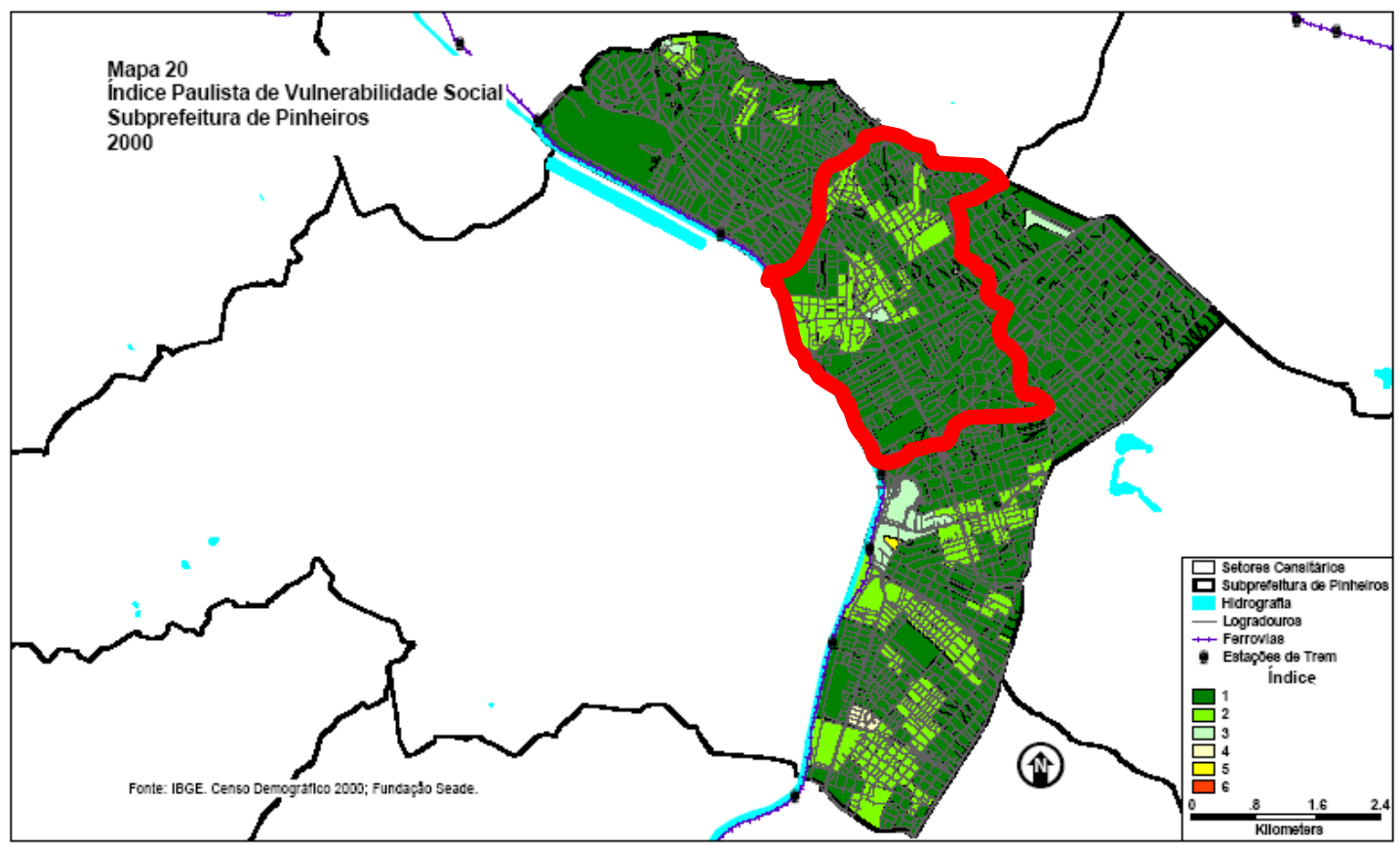

FIGURA 10 - Mapa do índice Paulista de Vulnerabilidade Social da Subprefeitura de Pinheiros.

Fonte: Mapa: SEADE - Subprefeitura de Municípios.

\subsection{Vila Mariana}

Ponciano (2001) nos conta que, tendo suas origens em uma sesmaria concedida a Lázaro Piques em 1782, a Vila Mariana teve impulso com a inauguração, em 1886, da estrada de ferro que ia de São Paulo a Santo Amaro. O então bairro de Mato Grosso aparentemente recebeu o nome da esposa do engenheiro responsável pela obra, Alberto Kuhlman e já em 1887 a Câmara Municipal se referia ao "bairro da Vila Mariana".

Por volta de 1891, José Antônio Coelho comprou a Chácara da Boa Vista e a loteou, abrindo alguns dos grandes eixos do bairro, como as ruas Central, Garibaldi e dos Italianos (hoje Humberto I, Rio Grande e Álvaro Alvim). Momentos de destaque foram proporcionados pela Villa Kyrial, que pertencia ao senador e mecenas José de Freitas Valle e ali organizava suas 


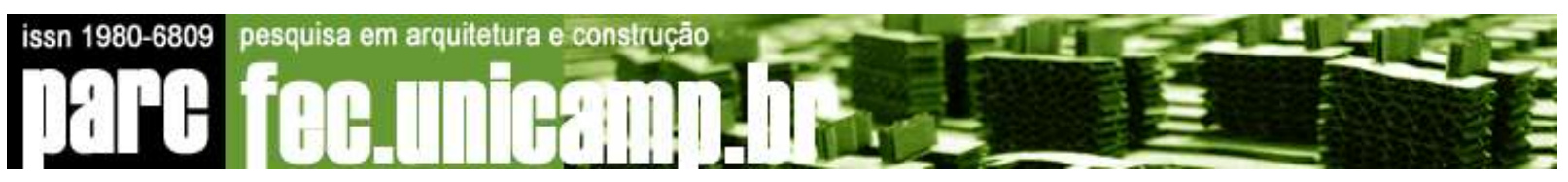

tertúlias. Com a conversão do antigo matadouro municipal a sede da Cinemateca Brasileira (1992) e a inauguração do SESC Vila Mariana (1997), o bairro passou a retribuir a influência cultural dos museus e atividades do Parque do Ibirapuera e da região da Avenida Paulista.

Uma análise da Vila Mariana, especificamente compreendida como a região compreendida pelo quadrilátero Av. 23 de Maio x R. Amâncio de Carvalho x Av. Sena Madureira x R. Domingos de Moraes revela um bairro que parece buscar um posicionamento próprio na cidade de São Paulo. Nota-se claramente uma transformação imobiliária e no comércio, que tem como epicentro a valorização da área limítrofe ao Parque do lbirapuera e perde intensidade, conforme se aproxima da Av. Domingos de Moraes. Se na primeira as casas de meados do século passado cedem lugar a mansões suspensas, na segunda abrem espaço a prédios de metragem exígua, cujo principal atrativo anunciado é a proximidade ao metrô (Paraíso, Ana Rosa ou Vila Mariana).

Entre os dois extremos estabeleceram-se as sedes do Unicentro Belas Artes, que ao longo dos últimos anos aquinhoou mais de vinte imóveis no bairro, preservando as construções originais e a Escola Superior de Propaganda e Marketing (com dois campi, FIGURA 11). Com isso, a Vila Mariana estabelece um diálogo crescente com a cidade, no qual abundam estabelecimentos de arte, serviços multimídia, escolas de formação artística e linguística, restaurantes e bares étnicos e multiculturais, além de uma vida noturna que sustenta a boemia dos estudantes.

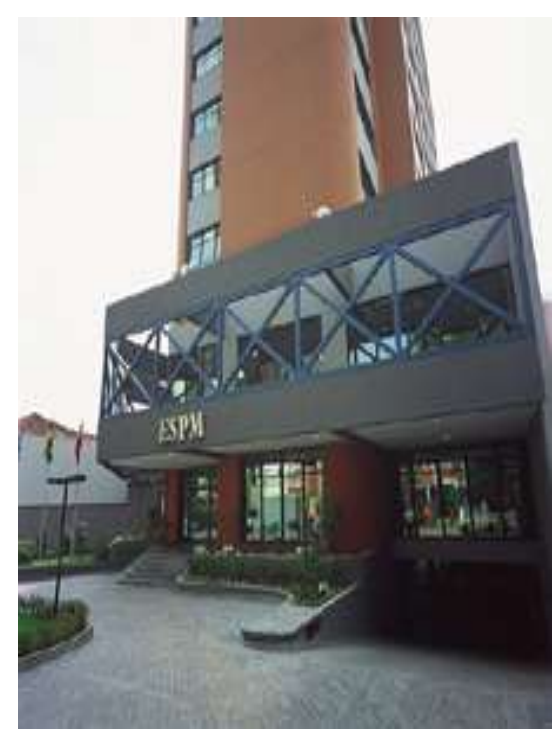

FIGURA 11 - Sede da ESPM na Rua Joaquim Távora.

FONTE: Ana Carla Fonseca Reis, 2007. 


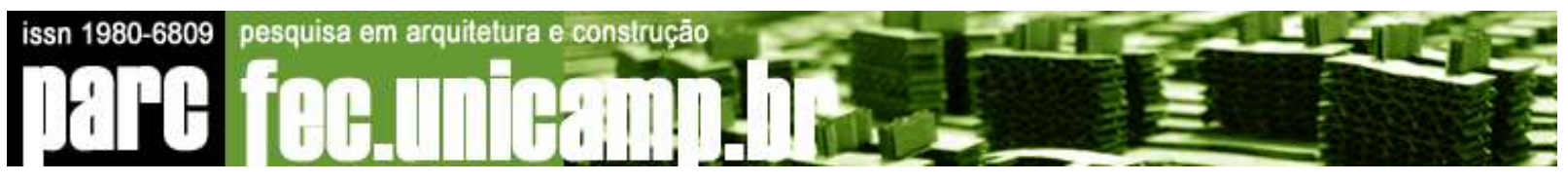

Paralelamente à arquitetura de época com exemplares icônicos, como o Instituto Biológico (projetado em 1928, na então várzea do "Campo do Barreto" e finalizado em 1945, FIGURA 12), encontram-se equipamentos culturais como a Cinemateca Brasileira (transferida em 1992 para o edifício do antigo Matadouro Municipal, iniciado em 1880 e tombado pelo Condephaat, FIGURA 13), cujo acervo de 200mil rolos de filmes apresenta obras desde 1895; e o SESC Vila Mariana (inaugurado em 1997), com arquitetura arrojada, tornando-se um marco do bairro e da cidade.

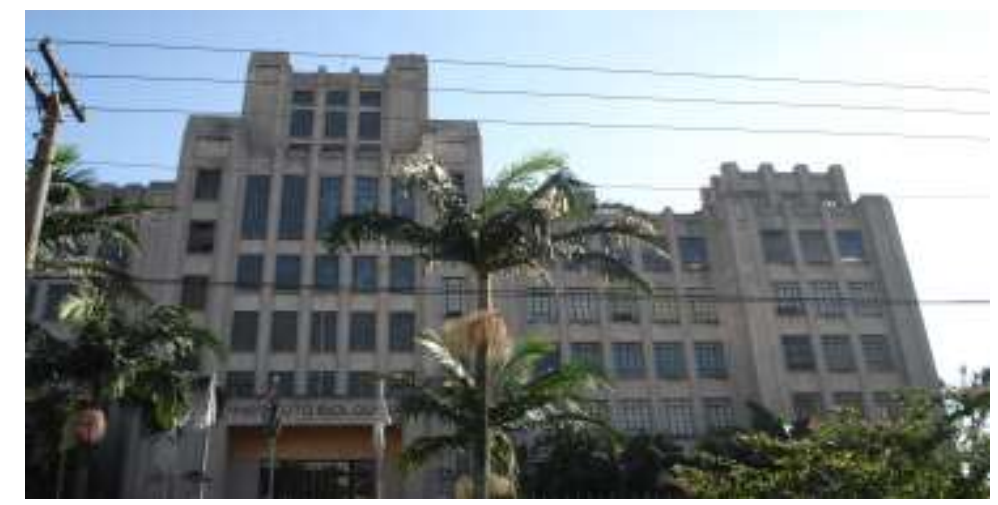

FIGURA 12 - Instituto Biológico

FONTE: Geise B. Pasquotto, 2007

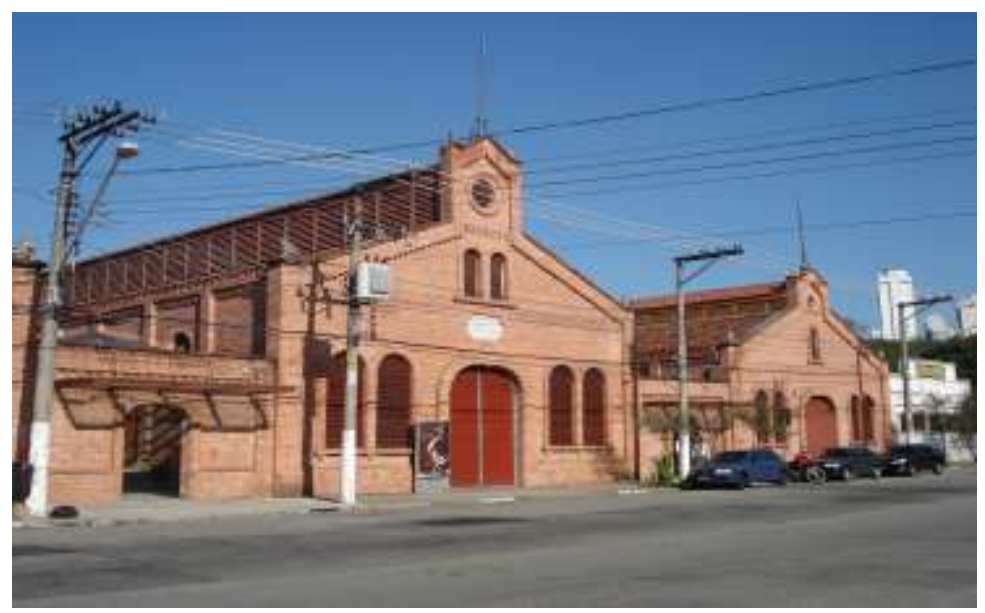

FIGURA 13 - Cinemateca Brasileira, no edifício do antigo Matadouro Municipal FONTE: Geise B. Pasquotto, 2007.

A partir de então, a Vila Mariana incrementou seu diálogo com os equipamentos culturais dos bairros contíguos, em especial os museus e a Bienal do Parque do lbirapuera; o trinômio Casa das Rosas-SESC Paulista-Itaú Cultural, no início da Avenida Paulista; e o Museu Lasar 


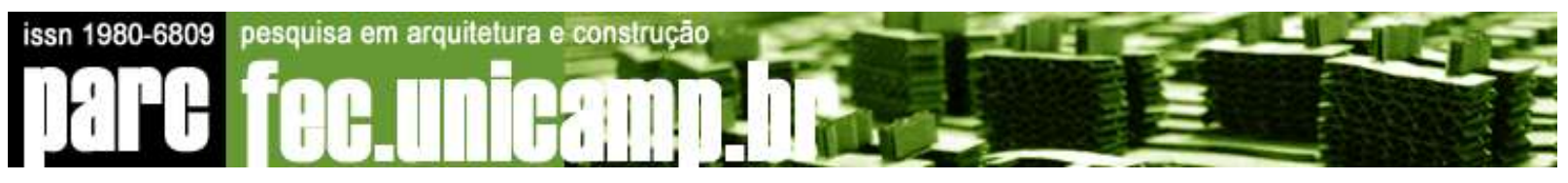

Segall, atravessando a R. Domingos de Moraes. O bairro deixou de ser uma área residencial e de comércio local, ladeado por regiões de maior vitalidade cultural, para se unir a eles e assumir a dianteira em novos desenvolvimentos acadêmico-culturais.

O posicionamento do bairro parece ainda estar em formação, construída a cada dia, por iniciativa exclusiva do setor privado (não foram identificadas obras de intervenção pública de nota, nos últimos quinze anos). Ao lado das novas construções persistem casarões e casebres antigos (FIGURA 14), uma miríade de ruas sem saída (que tão bem representam os bairros residenciais antigos de São Paulo, como se nota nas três vilas estudadas, FIGURA 15) e alguns resquícios do comércio de há um século, quando as compras se faziam na caderneta, a exemplo do Empório Rio Grande, de construção da década de 1920 (FIGURAS 16 e 17).

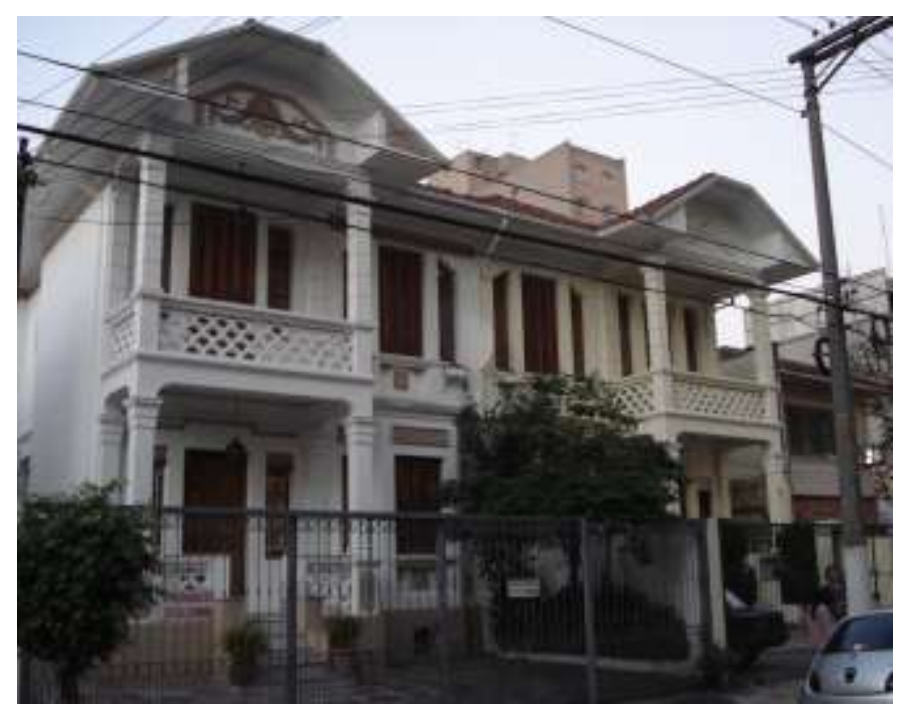

FIGURA 14 - Resquícios dos casas de época, Rua Humberto I.

FONTE: Ana Carla Fonseca Reis, 2007.

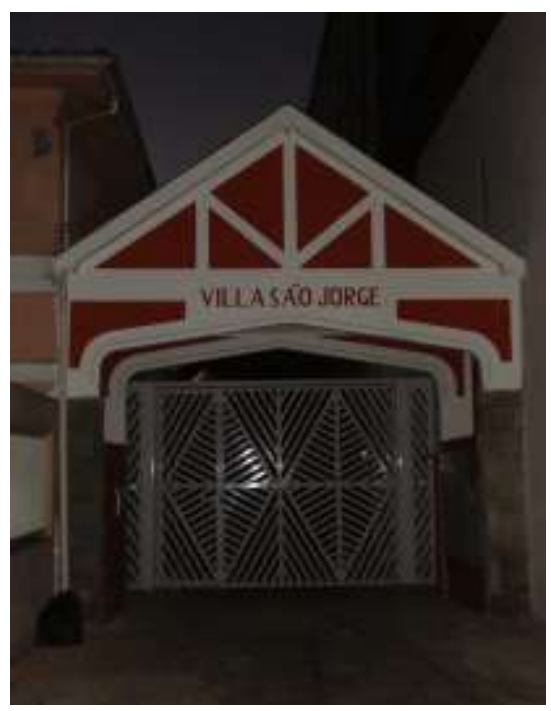

FIGURA 15 - Villa São Jorge, Rua Joaquim Távora.

FONTE: Ana Carla Fonseca Reis, 2007.

A multiculturalidade do bairro firma-se assim como um traço distintivo, reforçando a abertura ao exterior e uma imagem que vai se formando sem seguir um processo de planejamento do design urbano. 

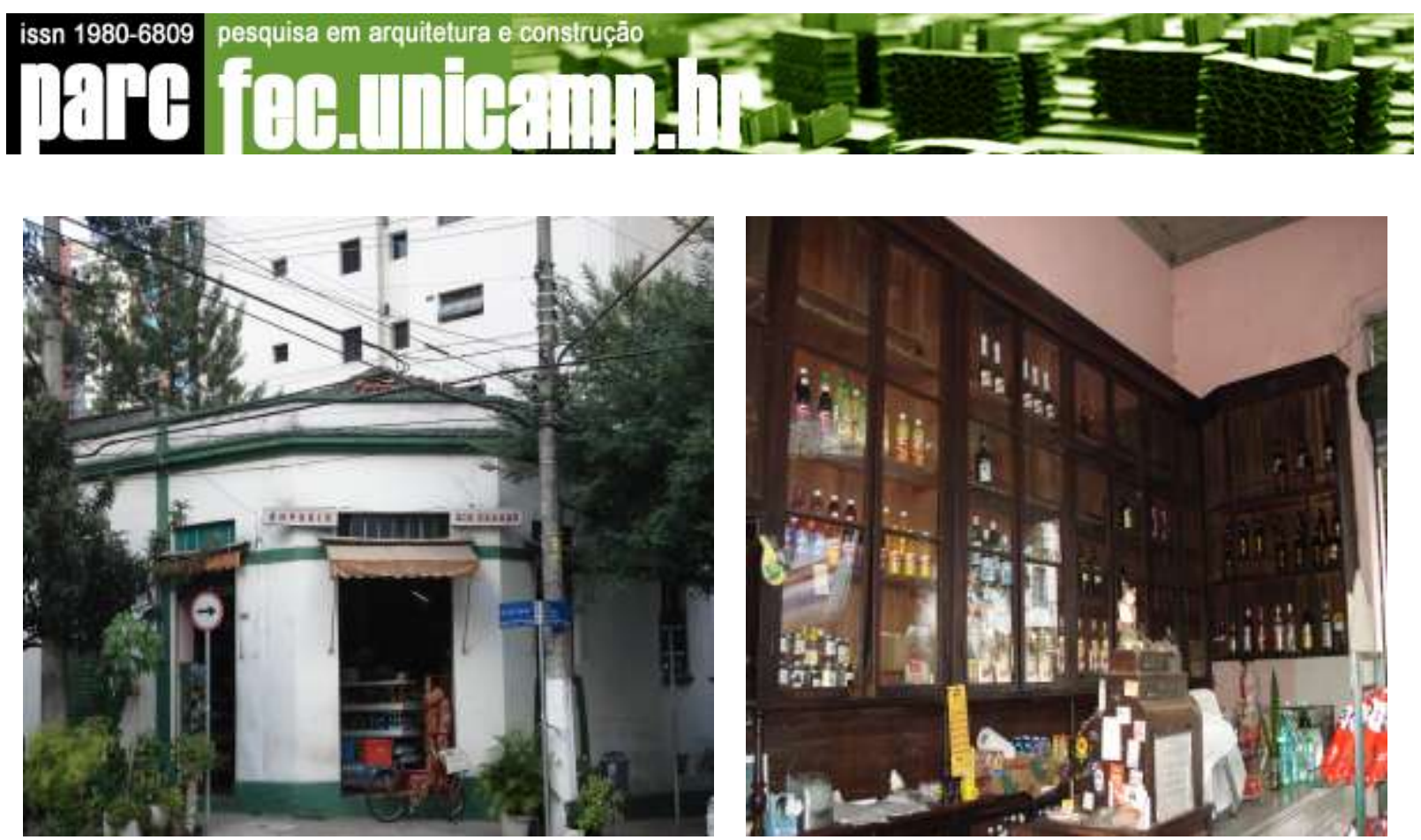

FIGURAS 16 e 17 - Fachada e interior do Empório Rio Grande, na esquina das Ruas Rio Grande e Morgado de Mateus.

FONTE: Ana Carla Fonseca Reis, 2007.

Parte dos problemas advindos é identificável na presença da única favela do bairro (FIGURA 18), que se estende ao longo de três quadras de uma única rua (Mário Cardim) e que é alvo recorrente das ações de inclusão socioeconômica do SESI e dos comerciantes locais.

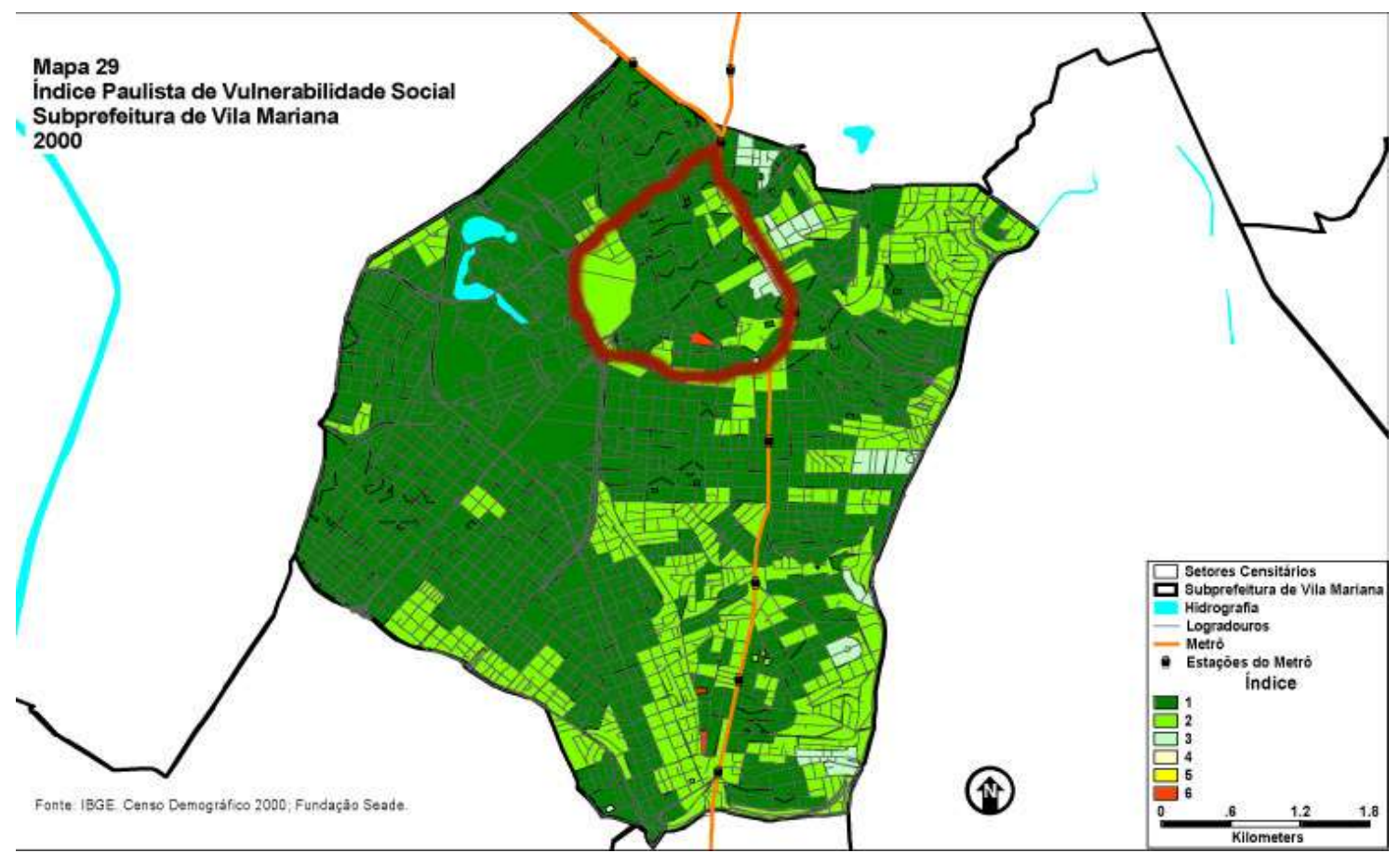

FIGURA 18 - Índice Paulista de Vulnerabilidade Social - Subprefeitura da Vila Mariana FONTE: Fundação SEADE, 2000. 


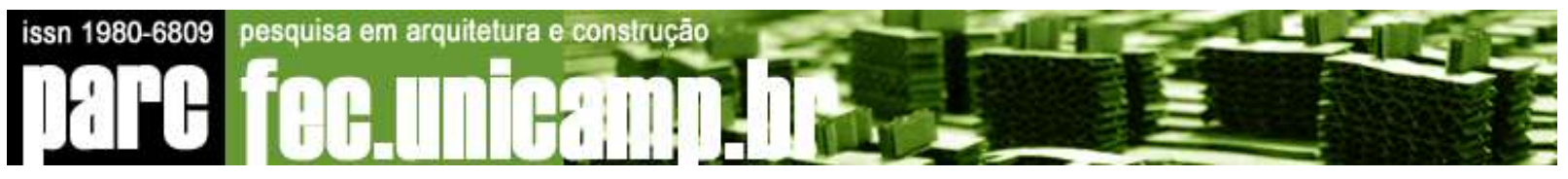

\subsection{Vila Leopoldina}

A Vila Leopoldina, situada na região Noroeste de São Paulo, era parte de um sítio intitulado Emboaçava de propriedade de João Correia da Silva e posteriormente pertenceu a jesuítas alemães. Desta forma, o sítio, que inicialmente possuía o casario dos religiosos, mais tarde foi ampliando-se tornando toda a área repleta de chácaras aos padres em meados de 1894. O primeiro e grande loteamento da Vila Leopoldina ocorreu em 1894, quando a empresa dona da área, E. Richter \& Company, "realizou uma jogada pulbicitária e alugou barcos para os futuros compradores conhecerem os lotes passeando pelo rio Tietê e participando de um piquenique para mais de quinhentos convidados" (PONCIANO, 2001). O nome atual do bairro surgiu nessa época em homenagem a D. Leopoldina Kleeberg, uma das sócias da empresa loteadora. O autor relata também que "mesmo com todo o esforço, o golpe publicitário não foi uma alavanca para o progresso da vila". O terreno era pantanoso, o que ocasionava muitas dificuldades na construção. No final de 1926, a empresa Incorporadora Siciliano \& Silva e o empresário Antônio Vilares lotearam aproximadamente 500 mil m2, retalhando-a em lotes urbanos. A ferrovia incentivou o surgimento das primeiras industrias em São Paulo que começaram a se expandir em direção a Vila Leopoldina, principalmente do ramo metalúrgico (PREFEITURA DE SÃO PAULO). Na década de 50 foi iniciada a construção do Centro Industrial Miguel Mofarrej, que deu nova vida à Vila. No lugar das antigas e ultrapassadas olarias vieram as grandes indústrias, e com elas o desenvolvimento. Em 1966 surgiu o CEASA (atual CEAGESP), que se tornou "um pequeno bairro do distrito da Vila Leopoldina" (PONCIANO, 2001).

Atualmente a Vila é um distrito situado na subprefeitura da Lapa e tem experimentado um acelerado processo de expansão imobiliária, fato esse que faz com que a região no entorno da Rua Carlos Weber seja conhecida como "Nova Moema", local que sofreu um processo semelhante na década de 70.

A Vila Leopoldina possui uma característica diferente das outras Vilas estudadas. Ela está em processo de formação, tanto de uma identidade cultural e estética quanto de uma identidade econômica. Portanto, a Vila oferece várias faces que mudam repentinamente, entre um local de galpões, um ambiente depredado, prédios de luxo e casas populares (FIGURA 19). 

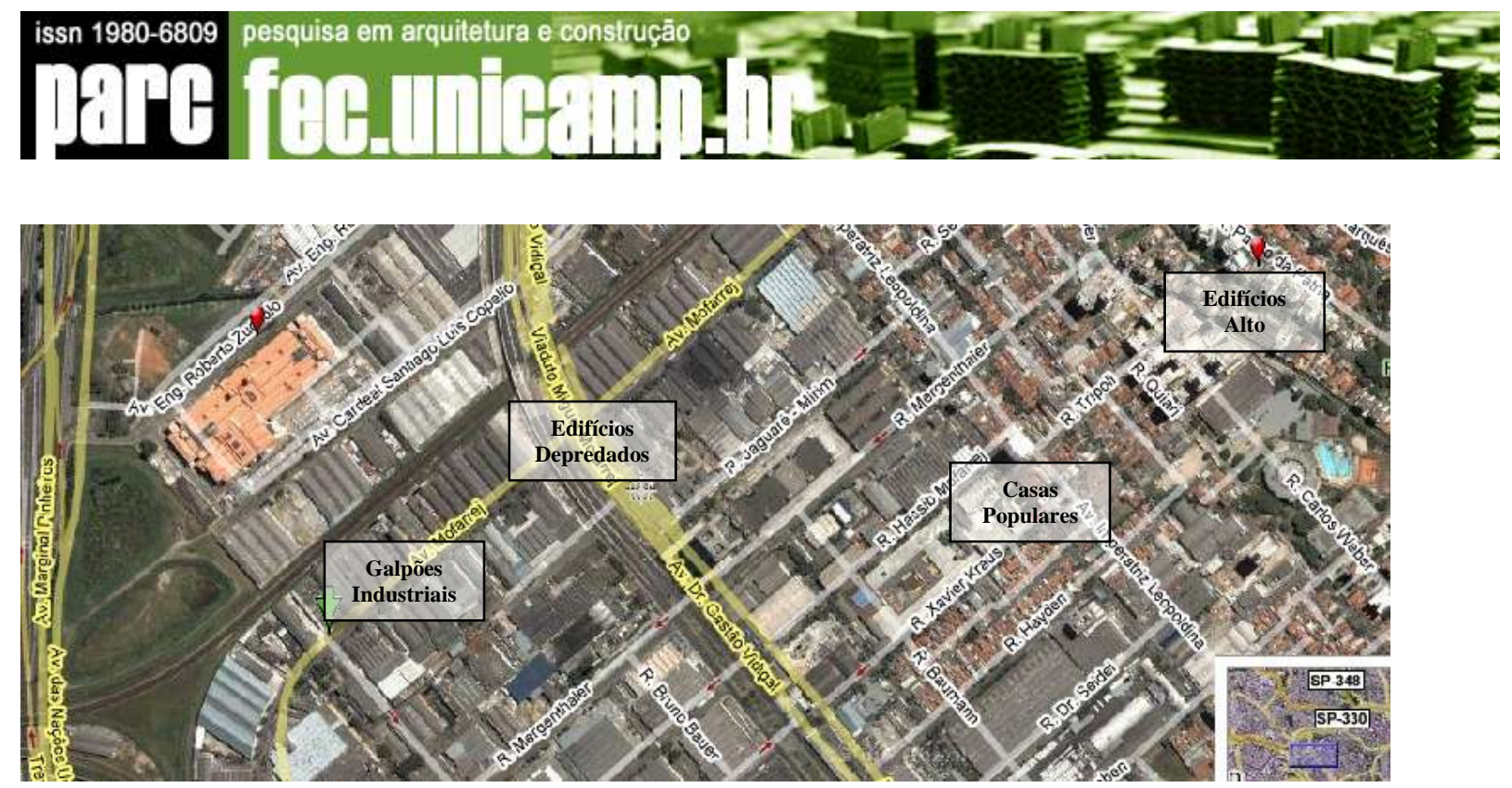

FIGURA 19- Foto aérea da Vila Leopoldina

Diferentes faces: de galpões industriais a edifícios de luxo.

FONTE: www.geobusca.net

A partir da Marginal Pinheiros situam-se os galpões industriais que remetem à história do bairro. Muitos deles já estão ocupados por grandes empresas e associações. Um exemplo disso é o CEAGESP (grande entreposto hortifrutigranjeiro), o Espaço Bic, a Agência de propaganda e marketing Neogama/BBH, as casas noturnas Pacha e Diquinta, entre outras.

O Espaço Bic (FIGURA 20) atualmente é um edifício de associações de escritórios, nos quais estão: Do it Comunicação, Eurofort São Paulo, Gênio Montagem, Artidea, Chico Design, Primo Filmes, Sixpix Content, Villas Boas e Vinil. O local de galpões industriais da fábrica de canetas da BIC foi reformado, preservando o estilo fabril e também a caixa D’Água em formato de caneta (FIGURA 21). 


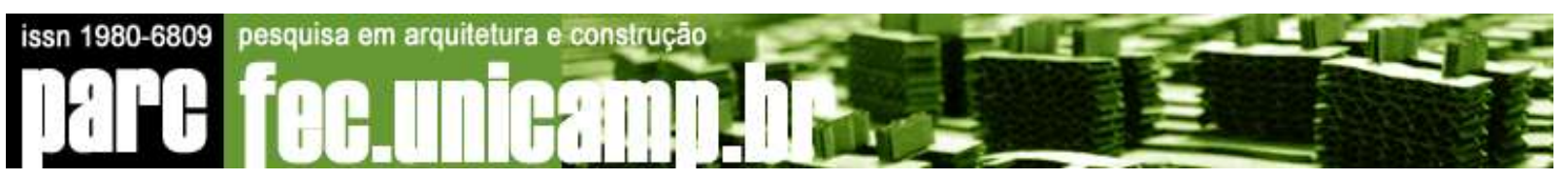

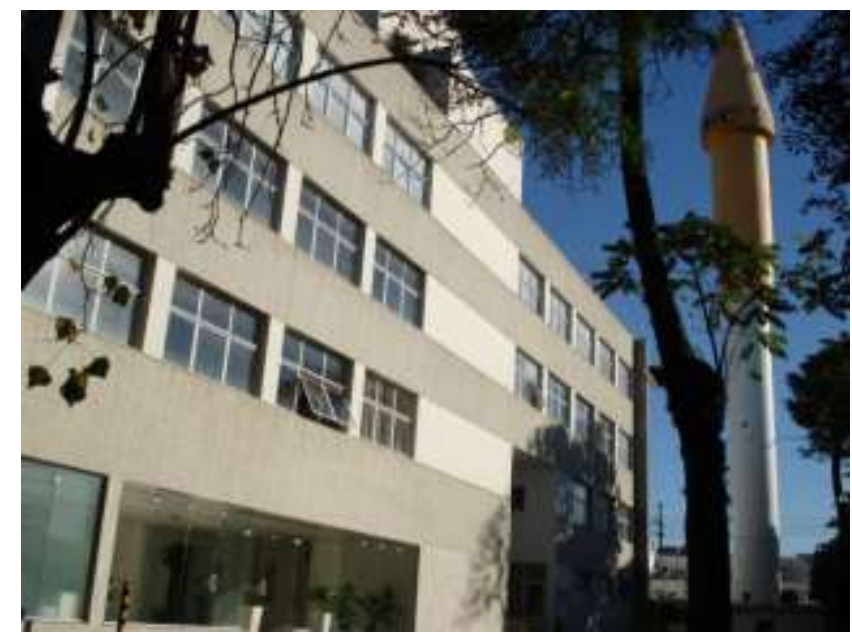

FIGURA 20 - Edifício do Espaço BIC. FONTE: Geise B. Pasquotto, 2007.

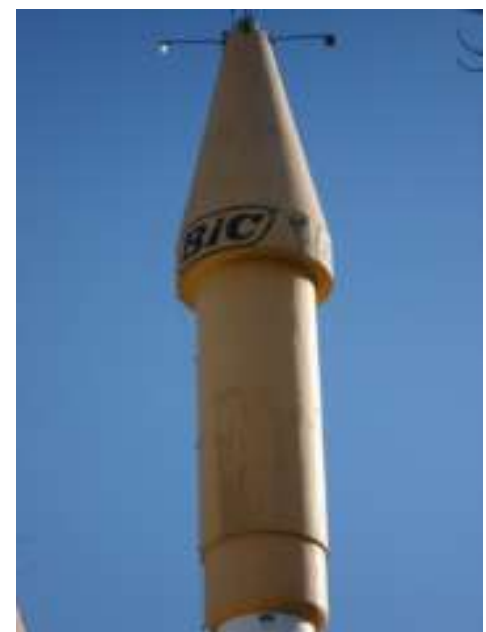

FIGURA 21 - Caixa D’Água em formato de caneta BIC.

FONTE: Geise B. Pasquotto, 2007.

A sede da Neogama/BBH, segundo o Portal da Propaganda, foi construída do zero e é um projeto único na América Latina (FIGURA 22 e 23). O objetivo foi criar um espaço moderno e inovador que integrasse a operação, trouxesse níveis inéditos de produtividade e refletisse 0 padrão de qualidade criativa e visual, que é uma marca do trabalho da agência.

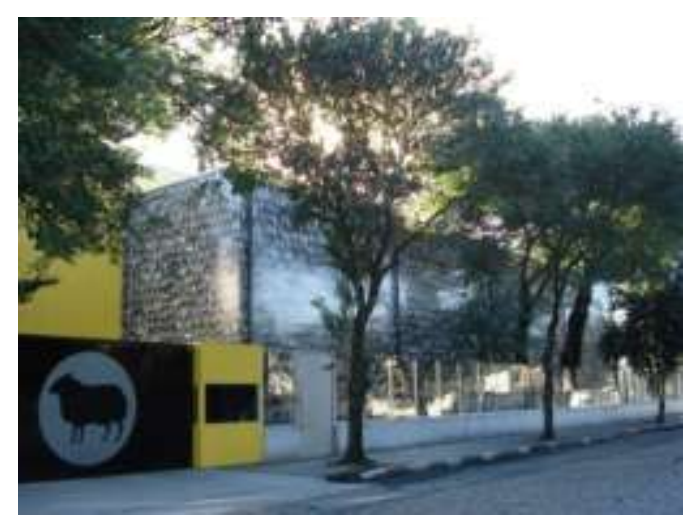

FIGURA 22 - Fachada da Agência Neogama/BBH

FONTE: Geise B. Pasquotto, 2007.

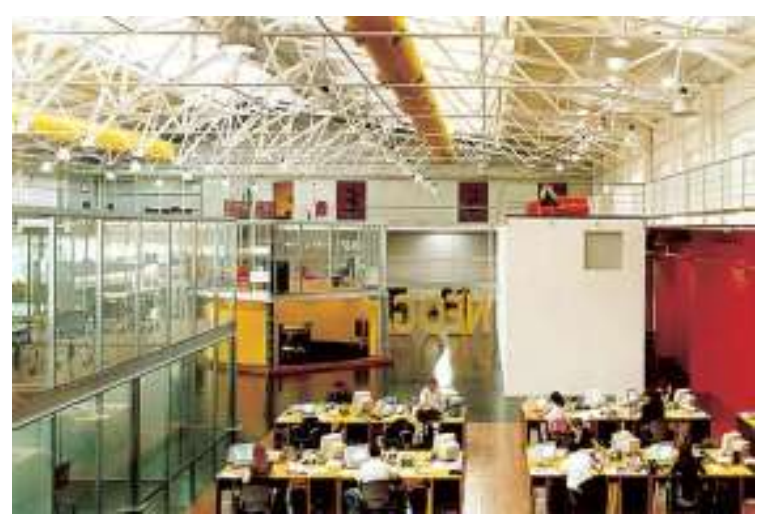

FIGURA 23 - Vista interna revela as extensas aberturas dos sheds e tubulações aparentes. FONTE: PROJETODESIGN, edição 308, 2005.

A casa noturna Paxá é uma empresa internacional que possui sua matriz em Ibiza, na Espanha. A "grife" conta com 20 estabelecimentos ao redor do mundo, em lugares como Nova lorque, Buenos Aires e até no balneário de Sharm El-Sheik (Egito). O Diquinta também 


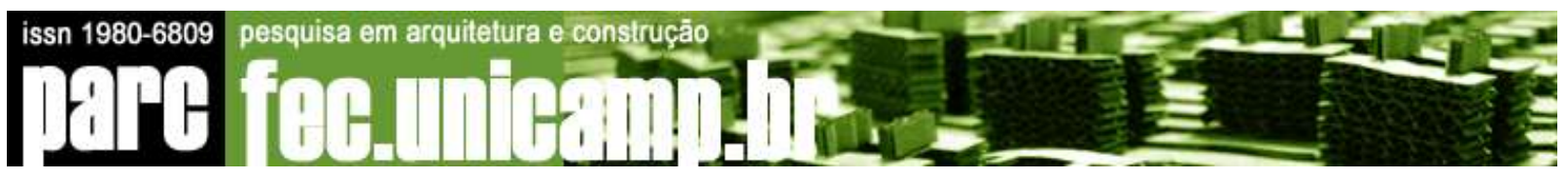

é uma casa noturna famosa da Vila Leopoldina, mas tem um público diferente da Pacha pela música samba-rock.

Nessa parte da região não se tem um diálogo com o externo (FIGURA 24 e 25), pois todas as entradas são fechadas com portaria, sendo proibida a entrada dos pedestres sem autorização prévia ou no caso das casas noturnas, sem o ingresso comprado.

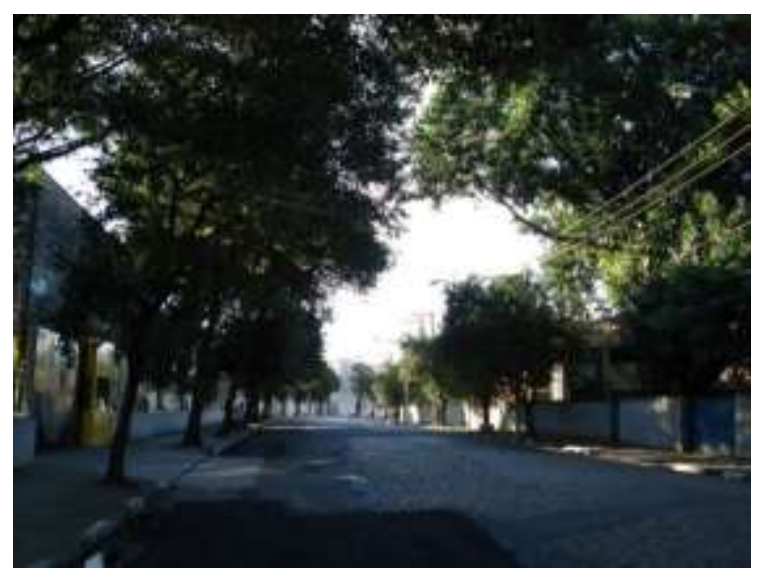

FIGURA 24 - Ruas sem interação com o espaço privado.

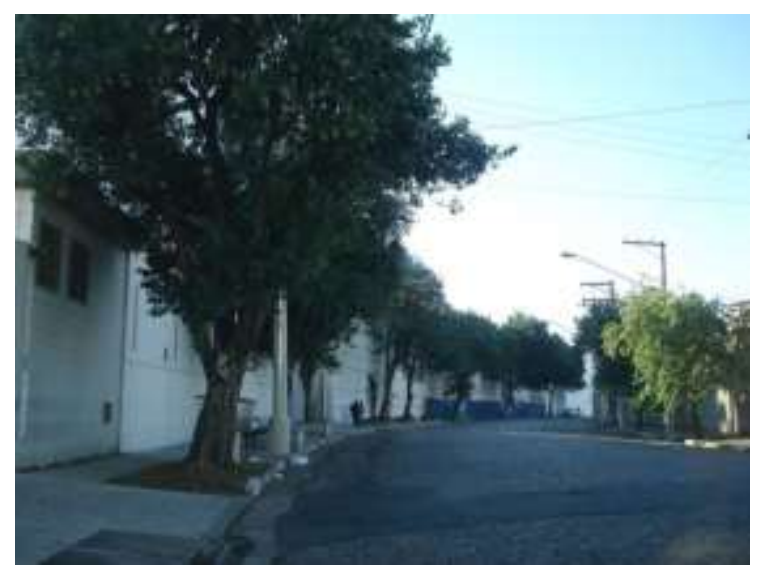

FIGURA 25 - "Paredões" voltados para a rua. FONTE: Geise B. Pasquotto, 2007.

FONTE: Geise B. Pasquotto, 2007.

Vale ressaltar que quase todas as edificações desse local não alteraram a forma de antigos galpões, apenas reformaram o exterior (FIGURA 26) e modificaram internamente (FIGURA 27), e as que realizaram modificações no edifício procuraram em suas diretrizes arquitetônicas remeter a construção fabril, como é o caso da agência de propaganda, que usou seu sistema de circulação de ar remetendo aos tubos dos galpões industriais (FIGURA 28) e da empresa Vezzani que buscou através de grafites essa relação (FIGURA 29). Este processo denota um posicionamento (diferenciação e Identidade de marca). 


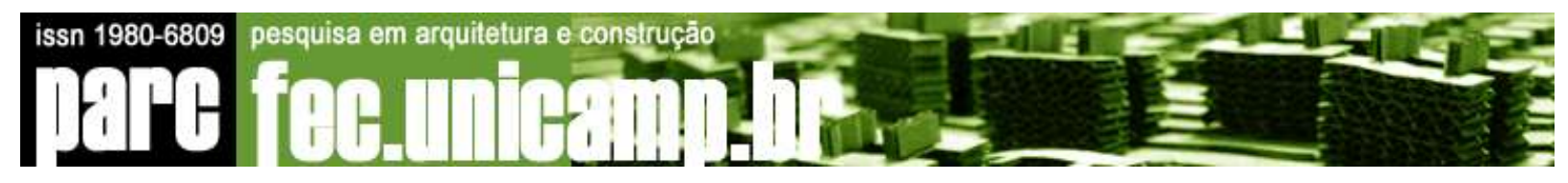

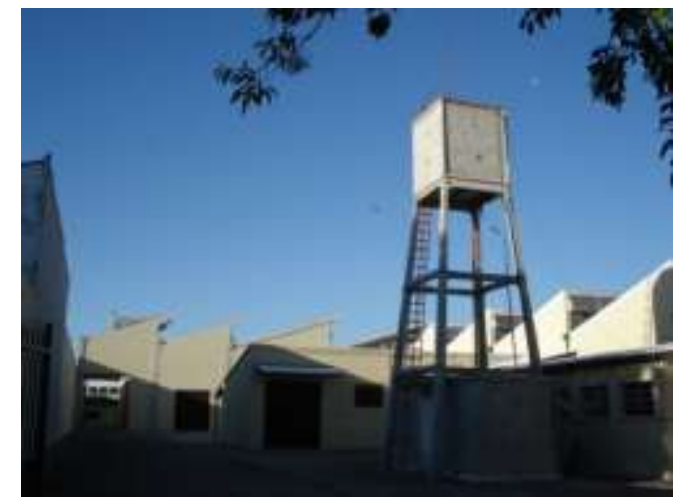

FIGURA 26 - Reforma no exterior da casa noturna Pacha.

FONTE: Geise B. Pasquotto, 2007.

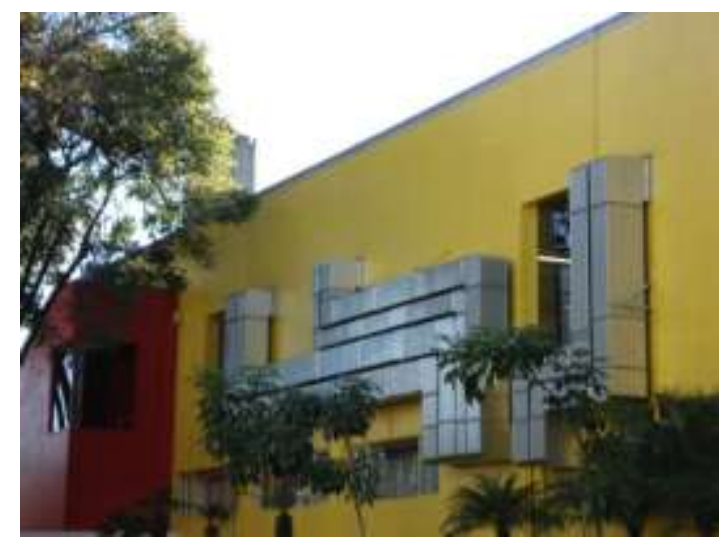

FIGURA 28 - O sistema de ventilação da Agência Neogama remetendo à arquitetura fabril.

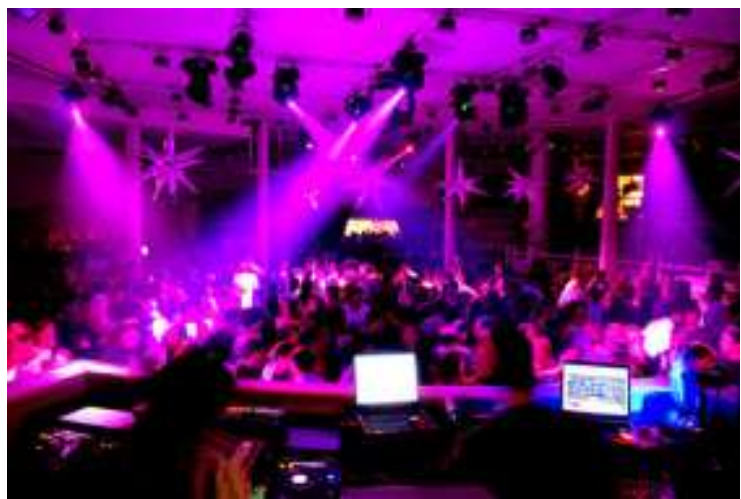

FIGURA 27 - Modificações internas da casa noturna Pacha.

FONTE: http://www.pachasp.com.br/.

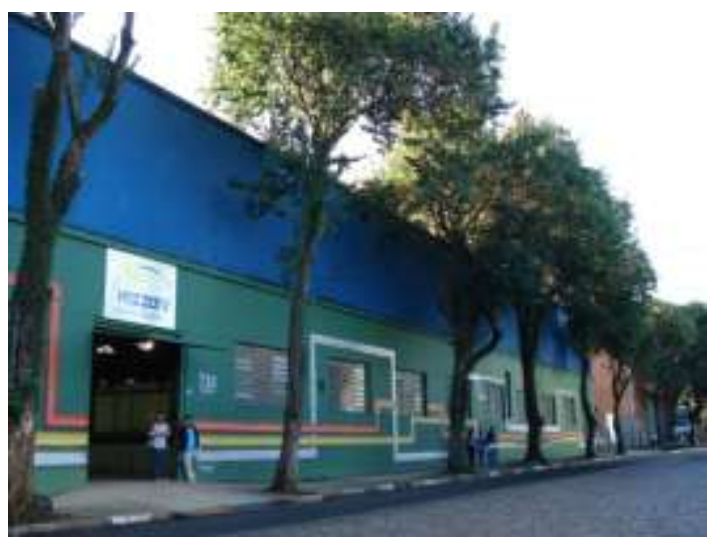

FIGURA 29 - Grafite em forma de tubulações na fachada da empresa Nezzani. FONTE: Geise B. Pasquotto, 2007. FONTE: Geise B. Pasquotto, 2007.

Afastando-se um pouco mais da Marginal ocorre um processo de decadência dos galpões, tornando-se um lugar depredado, com pichações, favelas, etc (FIGURA 30 e 31) 


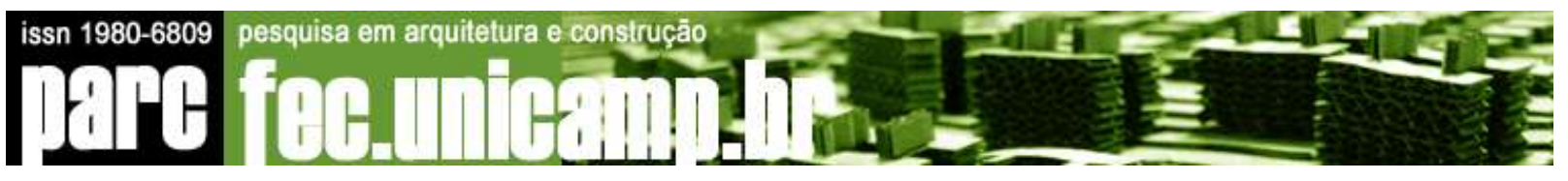

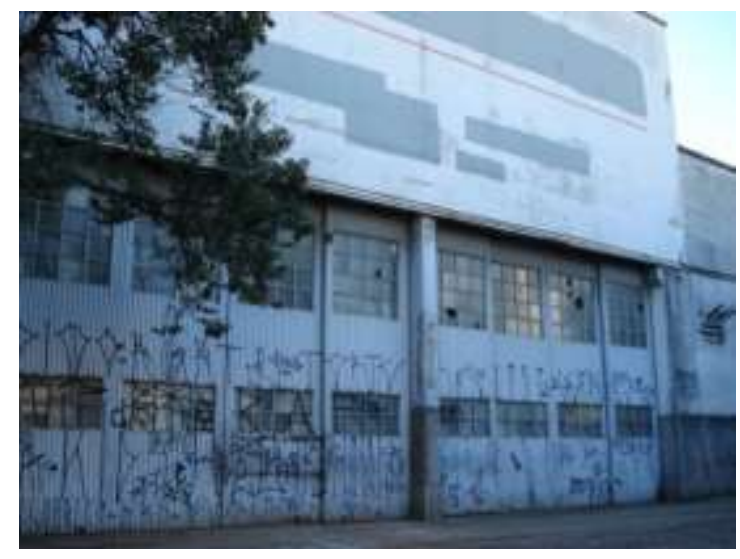

FIGURA 30 - Fachadas depredadas com pichações e maus tratos.

FONTE: Geise B. Pasquotto, 2007.

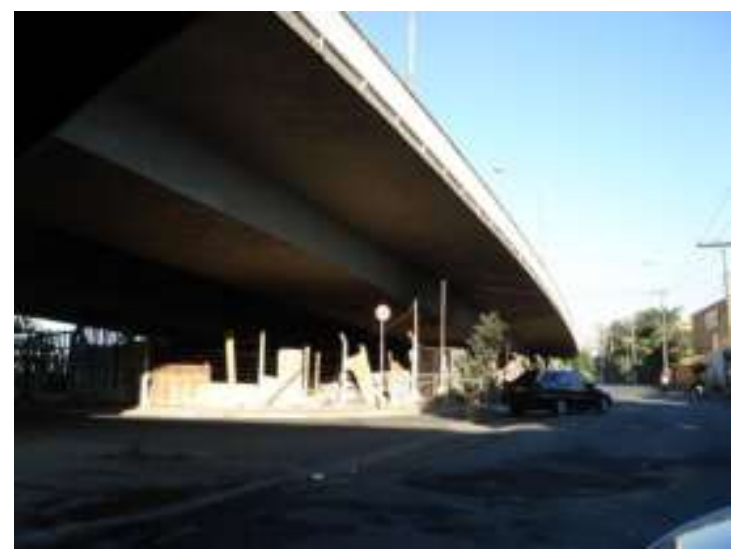

FIGURA 31 - Submoradias em baixo do pontilhão.

FONTE: Geise B. Pasquotto, 2007.

A partir da passagem do pontilhão, inicia-se outra face da Vila (FIGURA 32), mais popular e com uma especulação imobiliária em ampla expansão. Nessa área localizam-se grandes edifícios de luxo e casas populares que estão sendo encurraladas pelo processo de verticalização (FIGURA 33), se rendendo a incorporação de tendências do setor imobiliário.

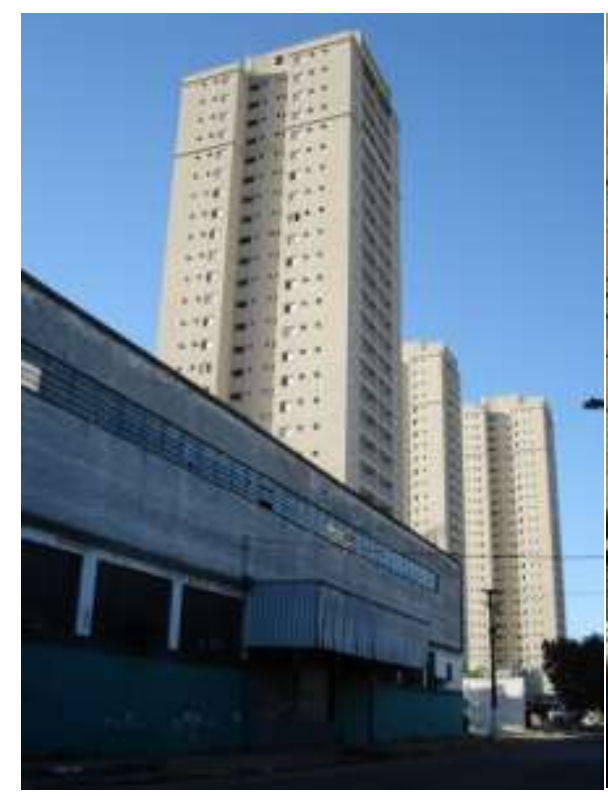

FIGURA 32 - O contraste estético e social da Vila.

FONTE: Geise B. Pasquotto, 2007.

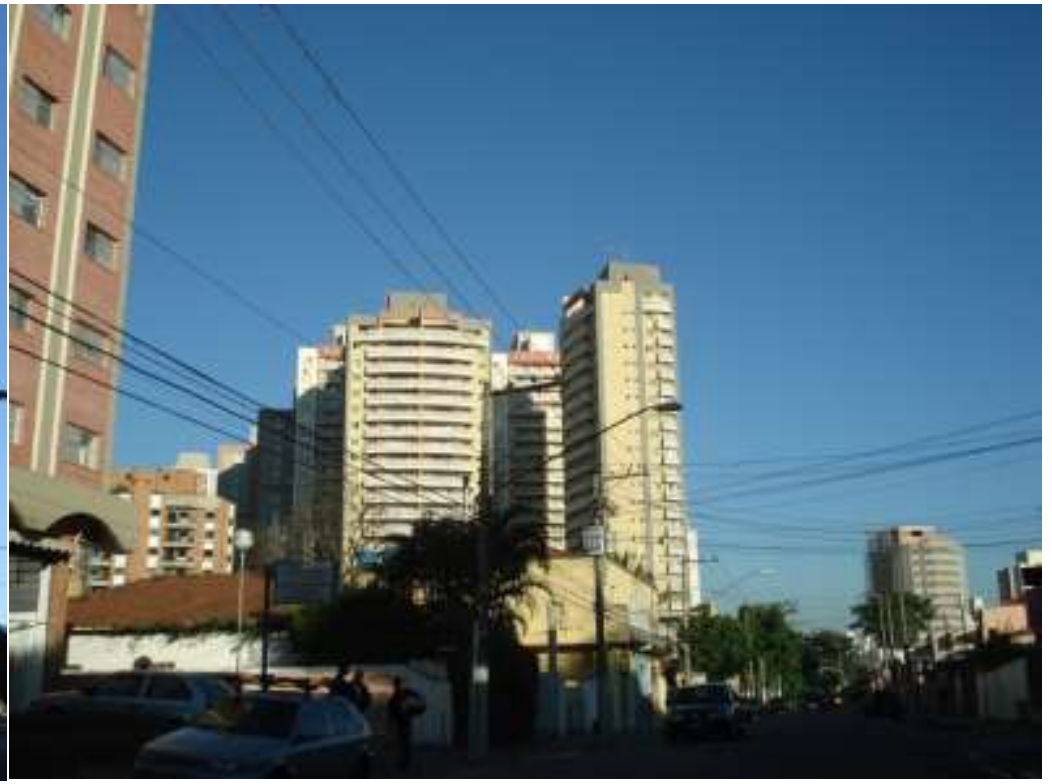

FIGURA 33 - Edifícios de alto padrão "esmagando" as casas populares.

FONTE: Geise B. Pasquotto, 2007. 


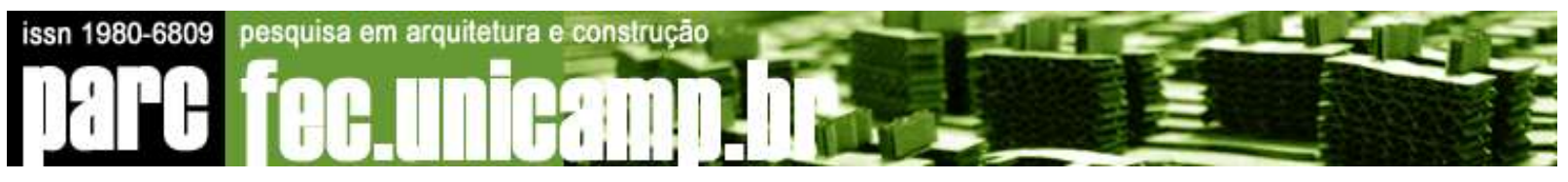

O Índice Paulista de Vulnerabilidade Social (FIGURA 34) indica essa múltipla característica social da Vila, possuindo desde o índice 1, que representa uma baixa vulnerabilidade social (pontos localizados na parte oposta a Marginal Pinheiros), e o índice 4 e 6, que demonstra uma degradação social nesses pontos (próximo ao viaduto e a Marginal). Esse processo indica as múltiplas dimensões que a Vila Leopoldina possui, tanto social como funcional e estética (como vimos nos itens acima citados).

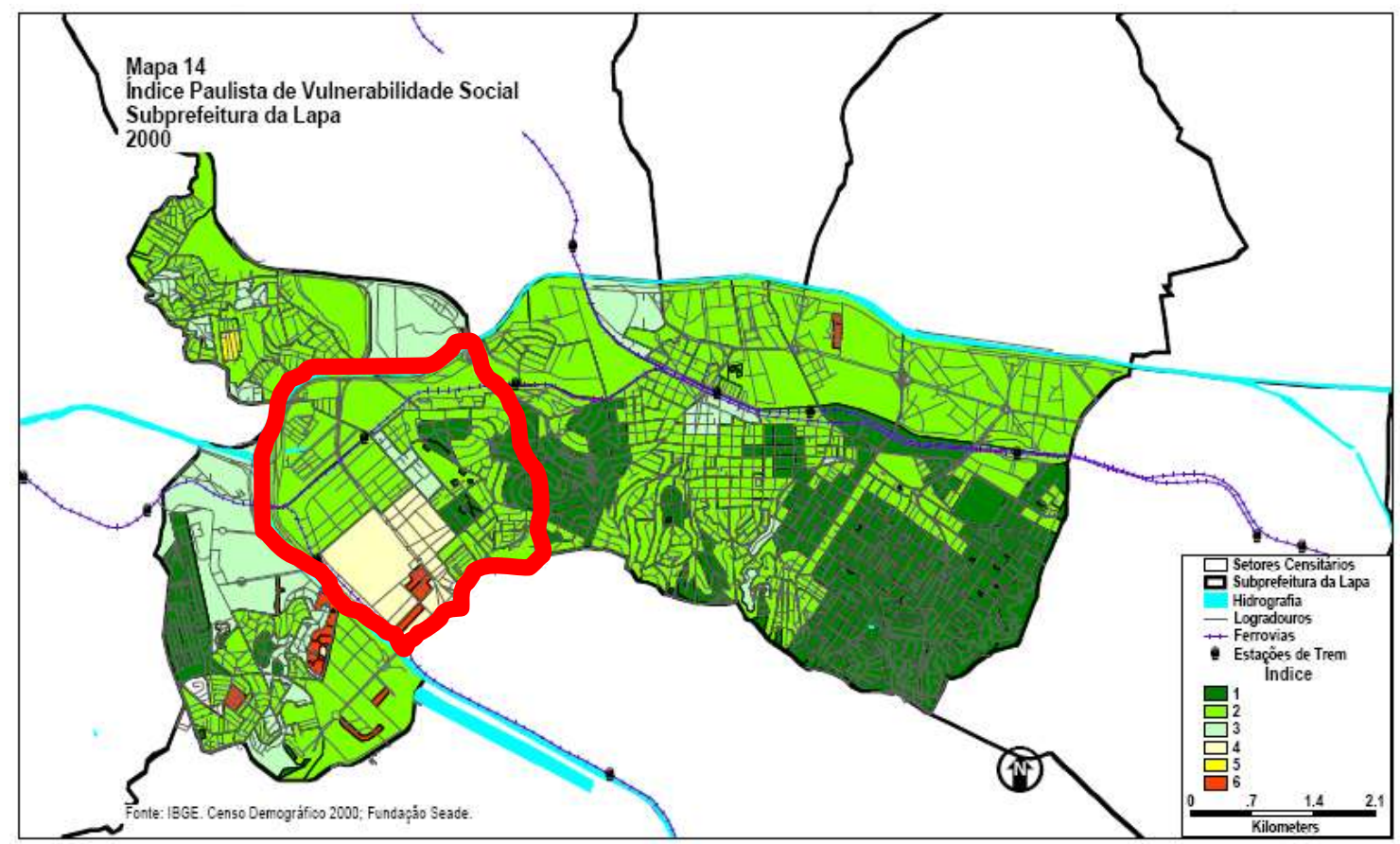

FIGURA 34 - Índice Paulista de Vulnerabilidade Social - Subprefeitura da Lapa FONTE: Fundação SEADE, 2000.

\section{Entrelaçamento dos conceitos e sua presença nas vilas}

A partir da análise das vilas analisadas foram identificados critérios que se encontram presentes nos três temas (cidades criativas, marketing urbano e visual merchandising), embora elaborados por cada um de forma distinta. Conforme sintetizado na Tabela 01, são eles:

- Diálogo com o externo - em termos macro, como a cidade se relaciona com o mundo; no micro, como o negócio dialogo com seu entorno.

- Posicionamento - envolve a identidade da marca (cidade ou negócio) e sua diferenciação frente às demais. 


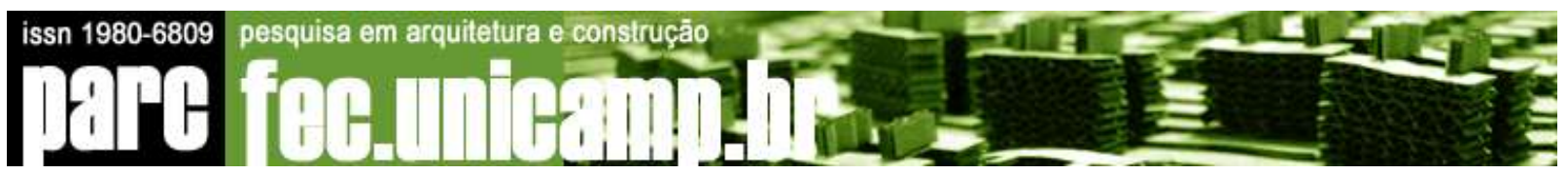

- Múltiplas dimensões - abrange a interpendência das dimensões estética, social e econômica na estratégia urbana ou empresarial.

- Parcerias - refere-se à presença e/ou papel desempenhado pelos setores público, privado, terceiro setor e academia e suas eventuais articulações em parceria.

- Atenção e incorporação de tendências - revela o grau de abertura, da cidade ou empreendimento, a absorver e ditar tendências, incorporar e fomentar inovação, adotar novas tecnologias e promover a diversidade.

TABELA 01 - Itens de intersecção dos temas abordados e suas especificidades.

\begin{tabular}{|c|c|c|c|}
\hline & Cidades Criativas & Marketing Urbano & Vitrina \\
\hline $\begin{array}{c}\text { Diálogo com o } \\
\text { Externo }\end{array}$ & $\begin{array}{l}\text { Diferenciação no } \\
\text { contexto cultural e } \\
\text { econômico mundial }\end{array}$ & $\begin{array}{l}\text { Divulgação mundial e } \\
\text { competitividade entre } \\
\text { as cidades globais. }\end{array}$ & Zona de Transição \\
\hline $\begin{array}{l}\text { Posicionamento } \\
\text { (diferenciação e } \\
\text { identidade de } \\
\text { marca) }\end{array}$ & $\begin{array}{l}\text { Identificação dos } \\
\text { setores econômicos e } \\
\text { culturais com maior } \\
\text { impacto mundial }\end{array}$ & $\begin{array}{l}\text { Utilização das } \\
\text { "marcas": do arquiteto, } \\
\text { do edifício e da } \\
\text { intervenção. }\end{array}$ & Identidade Corporativa \\
\hline $\begin{array}{c}\text { Multiplas } \\
\text { dimensões } \\
\text { (estética, } \\
\text { econômica, social) }\end{array}$ & $\begin{array}{c}\text { Crescimento e } \\
\text { desenvolvimento } \\
\text { baseados no binômio } \\
\text { social-econômico, com } \\
\text { forte inspiração cultural }\end{array}$ & $\begin{array}{c}\text { Valorização estética e } \\
\text { intervenções pontuais } \\
\text { em detrimento ao } \\
\text { master-plans. }\end{array}$ & $\begin{array}{c}\text { Estética: Composição / } \\
\text { Cor Iluminação } \\
\text { Funcional: } \\
\text { Social / Emotiva } \\
\text { Informativa }\end{array}$ \\
\hline Parcerias & $\begin{array}{c}\text { Público - Privado - } \\
\text { Terceiro Setor - } \\
\text { Academia }\end{array}$ & Público-Privado & $\begin{array}{c}\text { Privado-privado (stricto } \\
\text { sensu) } \\
\text { Público-privado- } \\
\text { terceiro setor (lato } \\
\text { sensu) }\end{array}$ \\
\hline $\begin{array}{c}\text { Atenção e } \\
\text { incorporação de } \\
\text { tendências }\end{array}$ & $\begin{array}{c}\text { Fundamental para } \\
\text { fomentar inovação, } \\
\text { tecnologia e garantir } \\
\text { diversidade }\end{array}$ & $\begin{array}{l}\text { Utilização do "novo" } \\
\text { como forma de } \\
\text { incrementar o turismo } \\
\text { e investimentos. }\end{array}$ & $\begin{array}{c}\text { Moda / Decoração } \\
\text { Design } \\
\text { Comportamento }\end{array}$ \\
\hline
\end{tabular}

FONTE: Tabela elaborada pelas autoras

Das breves análises relativas às Vilas Madalena, Mariana e Leopoldina, tendo por base os critérios de intersecção descritos ao longo deste artigo, confirma-se que cada vila possui, de fato, características, vocações e peculiaridades. De modo geral, o que se observa é que a Vila Madalena e a Vila Leopoldina localizam-se em pontos polarizantes das escalas de cada tópico, ao passo que a Vila Mariana se posiciona entre ambos.

Assim, no que tange ao diálogo com o externo, a Vila Madalena tem um caráter essencialmente aberto, dado não só pela apresentação das lojas e espaços presentes no 
bairro, como também graças aos produtos expostos à venda nas ruas e às feiras ao ar livre. A Vila Mariana traz um comércio com características semelhantes, porém seus espaços cívicos têm a tônica do interior - atividades na Cinemateca ou no SESC, aulas entre quatro paredes, deparando-se com um obstáculo entre o fruir e o entorno. Por sua vez, a Vila Leopoldina é toda voltada para dentro, em virtude das características de suas empresas (prestação de serviços business-to-business) e devido à ausência de comércio, serviços e atividades de rua, configurando um longo corredor murado.

Não por menos o posicionamento da Vila Leopoldina reflete uma diferenciação enquanto pólo de tecnologia e inovação audiovisual e de comunicações, ao passo que a Vila Mariana firma-se como centro acadêmico-cultural que respira e transpira diversidade e a Vila Madalena o comércio alternativo, o consumo diurno consciente e a boemia noturna jovem para todos os gostos.

A monolinguagem econômica marca assim a Vila Leopoldina, enquanto na Vila Madalena convivem múltiplas dimensões, em uma profusão de negócios e atividades econômicas, não raro voltadas ao social (como a iniciativa da Cidade Aprendiz) e que transitam pelo fluxo estético. A mesma configuração se faz presente na Vila Mariana, embora com formato distinto. Aqui, a estética passa a ser lapidar para a riqueza dos centros acadêmicos de propaganda, marketing e belas artes, bem como torna-se pedra de sustentação dos negócios e serviços oferecidos no bairro. Complementarmente, a oferta de uma programação cultural diversificada e de qualidade renomada, em diferentes instituições vizinhas, ocorre mediante ingressos de preço muito reduzido frente à média do mercado, incentivando o consumo cultural.

Apesar disso, a participação privada é a tônica na Vila Mariana, quando comparada a uma presença de parcerias mais marcantes do privado com instituições sem fins lucrativos e pontos de comércio solidário na Vila Madalena. Já quanto ao setor público, é somente na Vila Leopoldina que se faz relativamente mais presente, devido ao interesse recente do governo federal de incentivar o florescimento do audiovisual na região, em especial por meio de concessões de financiamento do BNDES (como o empréstimo de $\mathrm{R} \$ 7$ milhões do Departamento de Economia da Cultura à empresa Quanta).

Por fim, cumpre ressaltar a atenção e incorporação de tendências, que é notada nos três bairros, embora sob moldes distintos. Na Vila Madalena, a oferta de vários serviços em um mesmo estabelecimento, a presença de lojas de artesanato e moda alternativa e a variedade 


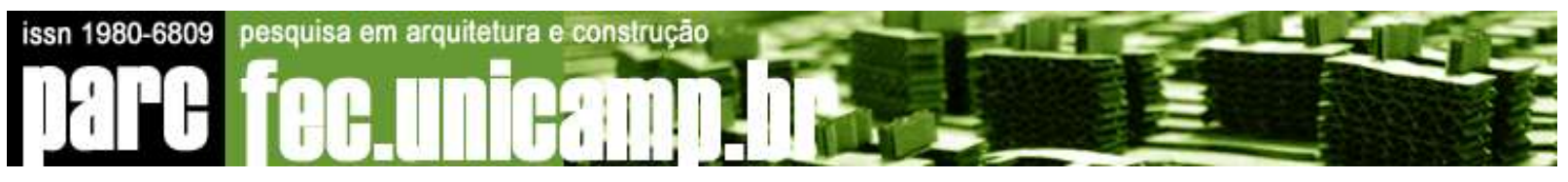

gastronômica são complementadas pela vivacidade noturna, que renova bares e restaurantes a uma velocidade vertiginosa. Na Vila Mariana, a antena voltada ao futuro se sustenta em dois pilares: os centros de debate acadêmico e as instituições culturais, de caráter francamente promotor da diversidade mundial. A Vila Leopoldina, por sua vez, vive de inovação e tecnologia, já pela própria característica de seus negócios e serviços de ponta (multimídia, tecnologia, comunicação).

Tabela 2 - Itens de intersecção dos temas abordados e sua aplicação nas três Vilas de estudo.

\begin{tabular}{|c|c|c|c|}
\hline & Vila Madalena & Vila Mariana & Vila Leopoldina \\
\hline $\begin{array}{l}\text { Diálogo com o } \\
\text { externo }\end{array}$ & $\begin{array}{c}\text { Zona de transição de: Lojas } \\
\text { / Bares / Restaurantes / } \\
\text { Ateliês. Feiras e comércio } \\
\text { ao ar livre } \\
\text { Presença do imaginário da } \\
\text { vila na cidade }\end{array}$ & $\begin{array}{c}\text { Comércio de rua, } \\
\text { centros acadêmicos } \\
\text { fervilhantes, } \\
\text { equipamentos culturais } \\
\text { promotores de acesso } \\
\text { Diálogo urbano em } \\
\text { crescimento, } \\
\text { especialmente com } \\
\text { bairros vizinhos }\end{array}$ & $\begin{array}{l}\text { Fechado (com indícios de } \\
\text { uma abertura) } \\
\text { Inexpressividade no } \\
\text { imaginário paulistano e } \\
\text { falta de diálogo com o } \\
\text { próprio bairro }\end{array}$ \\
\hline $\begin{array}{l}\text { Posicionament } \\
\text { o } \\
\text { (diferenciação } \\
\text { e identidade } \\
\text { de marca) }\end{array}$ & $\begin{array}{l}\text { Posicionamento de bairro } \\
\text { "descolado", de comércio } \\
\text { alternativo, locais diurnos } \\
\text { de consumo consciente e } \\
\text { boemia noturna }\end{array}$ & $\begin{array}{l}\text { Centro acadêmico- } \\
\text { cultural, com serviços e } \\
\text { negócios que gravitam } \\
\text { ao seu redor } \\
\text { Gastronomia } \\
\text { multicultural e boemia m } \\
\text { formação, lojas de ponta } \\
\text { em emergência }\end{array}$ & $\begin{array}{l}\text { Pólo de comunicação e } \\
\text { audiovisual, voltado } \\
\text { essencialmente a } \\
\text { negócios }\end{array}$ \\
\hline $\begin{array}{l}\text { Multiplas } \\
\text { dimensões } \\
\text { (estética, } \\
\text { econômica, } \\
\text { social) }\end{array}$ & $\begin{array}{c}\text { Grafites / Mosaicos } \\
\text { Exposição dos produtos à } \\
\text { venda / Feira da Vila / Feira } \\
\text { da Benedito Calixto Lojas } \\
\text { especializadas: brinquedos, } \\
\text { design, livraria, molduraria, } \\
\text { etc. Bares GLS / Música } \\
\text { Função: Social, Emotiva e } \\
\text { Informativa }\end{array}$ & $\begin{array}{l}\text { Estética baseada no } \\
\text { trinômio negócios } \\
\text { diferentes/centros } \\
\text { acadêmicos de } \\
\text { comunicação e } \\
\text { artes/equipamentos } \\
\text { culturais } \\
\text { Sustentação econômica } \\
\text { de negócios e acesso } \\
\text { social à programação }\end{array}$ & $\begin{array}{l}\text { Monolinguagem } \\
\text { econômica }\end{array}$ \\
\hline Parc & Privado- & Privado-Privado & Público-Privado \\
\hline $\begin{array}{c}\text { Atenção e } \\
\text { incorporação } \\
\text { de tendências }\end{array}$ & $\begin{array}{l}\text { Moda / Design / Brechós } \\
\text { Comportamento } \\
\text { (entretenimento) } \\
\text { Serviços: Gastronomia } \\
\text { Vários serviços no mesmo } \\
\text { estabelecimento }\end{array}$ & $\begin{array}{l}\text { Debates acadêmicos, } \\
\text { programação } \\
\text { multicultural, comércio e } \\
\text { restaurantes com } \\
\text { posicionamentos } \\
\text { distintos }\end{array}$ & $\begin{array}{l}\text { Negócios e serviços de } \\
\text { ponta (multimídia, } \\
\text { tecnologia, } \\
\text { comunicações) } \\
\text { Especulação Imobiliária }\end{array}$ \\
\hline
\end{tabular}

FONTE: Tabela elaborada pelas autoras. 


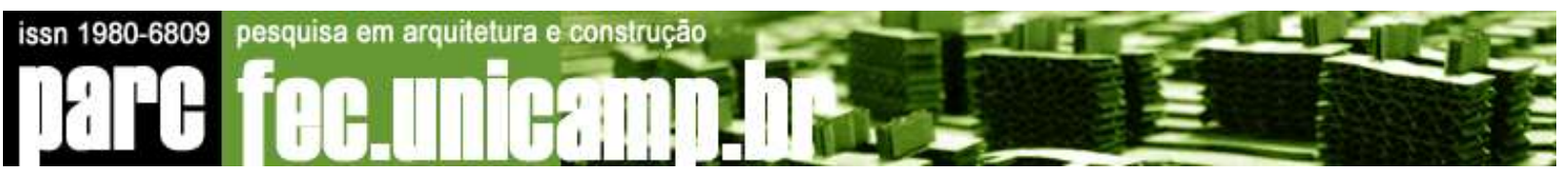

\section{Referências}

BENACH, Nuria, Ciutat i Producció d'imatge: Barcelona 1979-1992. Tesis Doctoral, Departamento de Geografia Humana, Universitat de Barcelona, 1997.

BIGAL, Solange Vitrina: do outro lado do visível. São Paulo: Nobel, 2001.

CANADIAN POLICY RESEARCH NETWORKS (CPRN), Creative Cities Structured Policy Dialogue Backgrounder. Org. by Neil Bradford, 2004. Disponível em $<$ www.cprn.com/doc.cfm?doc=1081\&l=en> Acessado em 06/06/07.

CASTELLS, Manuel, "La Ciudad de la nueva economía”. La Factoria, Junio-Septiembre 2000, n.12. Disponível em <http://www.lafactoriaweb.com/articulos/castells12.htm> Acessado em 06/06/07.

CREATIVE CLUSTERS CONFERENCE, www.creativeclusters.com

DEMETRESCO, Sylvia Vitrina: teu nome é sedução. Pancrom,1990.

DEPARTMENT FOR CULTURE, MEDIA AND SPORT (DCMS), Reino Unido, $<$ www.dems.gov.uk>

EUROPEAN COMMISSION, The Economy of Culture in Europe, October 2006. Disponível em <http://ec.europa.eu/culture/eac/sources_info/studies/economy_en.html> Acessado em 06/06/07.

FUNDAÇÃO SEADE, Informações dos Distritos da Capital. Disponível em $<$ <ww.seade.gov.br> Acessado em 06/06/07.

GRUNOW, Evelise, Cobertura e iluminação sofisticam ambiente de origem industrial. Revista PROJETODESIGN, Edição 308, Outubro de 2005.

INSTITUTO BRASILEIRO DE GEOGRAFIA E ESTATÍSTICA (IBGE), Sistema de Informações e Indicadores Culturais 2003. Disponível em <www.ibge.gov.br> Acessado em 06/06/07.

LOPES, Rodrigo, A Cidade Intencional: o planejamento estratégico de cidades. Rio de Janeiro: Editora Mauad, 1998.

PASQUOTTO, Geise B. Edifícios Culturais e a Reabilitação de Áreas Centrais: o Complexo Cultural Teatro da Dança de São Paulo. Dissertação de Mestrado, Unicamp, 2011.

PONCIANO, Levino, Bairros Paulistanos de A a Z. São Paulo: Ed. Senac, 2001. 450 bairros, São Paulo, 450 anos. São Paulo: Ed. Senac, 2004.

PORTAL DA PROPAGANDA, "Neogama/BBH". Disponível em $<$ www.portaldapropaganda.com> Acessado em 03/06/07. 


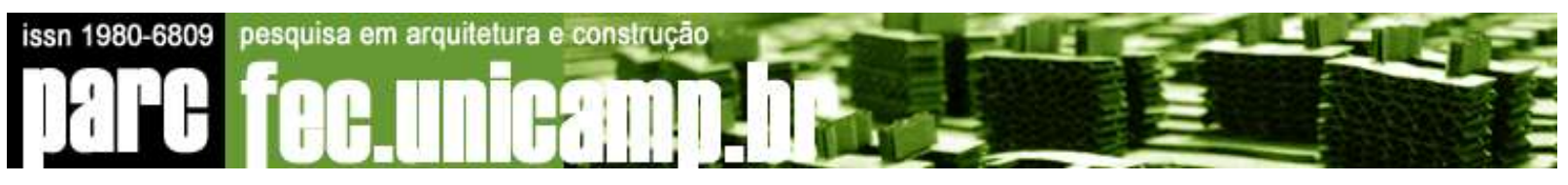

PREFEITURA DE SÃO PAULO, "Origem da Lapa remonta aos primórdios do povoamento de São Paulo de Piratininga". Disponível em < http://portal.prefeitura.sp.gov.br/subprefeituras/spla/dados/historico/0001> Acessado em 19/05/07.

SANCHEZ, Fernanda, Cidade Espetáculo: Política, Planejamento e City Marketing. Curitiba: Palavra, 1997.

"Buscando um lugar ao sol para as cidades: O Papel das atuais políticas de promoção urbana". Revista Paranaense de Geografia, n. 4. Curitiba, Associação dos Geógrafos Brasileiros - AGB Curitiba, 1999. Disponível em <www.agbcuritiba.hpg.ig.com.br/Revistas/Rpg3/4fernanda.htm> Acessado em 03/02/06.

"Políticas Urbanas em Renovação: uma leitura crítica dos modelos emergentes". Revista Brasileira de Estudos Regionais e Urbanos, edição n. 01, p.115132, 1999.

TUPIDATABA Disponível em http://tupidataba.blogspot.com Acessado em 01 de Junho de 2007.

VILA MADALENA (Site Oficial) Disponível em <www.vilamada.com.br/conteudo/historia.html> Acessado em 03 de Maio de 2007.

WIKIPEDIA, "Vila Leopoldina". Disponível em <http://pt.wikipedia.org/wiki/Vila_Leopoldina> Acessado em 19/05/07. 